\title{
Prehistoric Interactions in Eurasia: A Re-evaluation of Bronze Age Remains in the Oases on the Southern Rim of the Tarim Basin
}

\author{
By Marcella Festa*
}

Chinese Xinjiang, located on the "Silk Road" has played a pivotal role as a crossroad of east-west exchanges since prehistory. The oases on the southern rim of the Tarim Basin have been especially important in this system of interactions, as demonstrated by archaeological remains of early cultures, whose indigenous developments and external influences are often difficult to distinguish. Specifically, funerary evidence dating back to the Bronze Age shows similarities not only with neighbouring cultural groups in Xinjiang, but also with the steppe cultures and the farming traditions of Central Asia. Thus, despite the relatively low number of the excavated sites, Bronze Age remains found in the oases in southern Xinjiang are of great interests and high significance for the understanding of the prehistory of Xinjiang and Central Asia. By taking a omni-comprehensive approach, including paleo enviromental surveys, typological studies on the archaeological remains, metallurgical analysis and anthropological examinations, the purpose of this paper is to study the evidence from the southern rim of the Tarim Basin in greater detail than has yet been attempted. Moreover, by re-examining the information within a broader Eurasian context this paper intends to give a contribution to the understanding of the prehistoric interactions among various regions.

\section{Introduction}

The oases on the southern rim of the Tarim Basin formed over the course of prehistory on the highlands and lowlands along the rivers that crossed the desert. The highlands have been inhabited since $8000 \mathrm{BCE}$, as demonstrated by the discovery of several Mesolithic sites in the valleys contained in the Kunlun mountains ${ }^{1}$. Similarly, ancient remains dating to the Stone Age were recovered from high-altitude sites, on the upper course of the Keriya River, in the valleys of the Kala Tashen mountains ${ }^{2}$, and on the A'erjin mountain range $^{3}$. In later periods, it seems that larger areas were occupied and, in fact, traces of human activity during the Metal Ages were found in both regions, in the highlands and lower sites along rivers, deep into the desert. These sites,

${ }^{*} \mathrm{PhD}$ Candidate, Ca' Foscari University of Venice, Italy.

1. Huang X., and Z. Wu, "Two groups of stone remains discovered on the upper reaches of Keriya river," in New results of archaeological research in Xinjiang (1990-1996), ed. by Xinjiang Wenwu Kaogu Yanjiusuo [Xinjiang Institute of Archaeology] (Urumqi: Xinjiang meishu shejing chubanshe 1997: 44-56).

2. Among others, the sites of Ashenluke and Xiaopuyu. X. Huang and Z. Wu, Two groups of stone remains discovered on the upper reaches of Keriya river, 1997: 44-56.

3. Among others, ancient remains were recovered in the villages of Ka'erdun and Yunuquan. B. Wang, X. Xiao, W. Liu, and W. Liu, "Microliths of Aerjin Mountains," Xinjiang Wenwu [Xinjiang cultural relics], no.4 (1997): 14-19. 
dating to the Bronze Age, are the subjects of this research, and specifically the settlements of Niya Beifang and Keriya Beifang and the cemeteries of Liushui and Zagunluke (Figure 1). Actually, other remains have been found scattered throughout southern Xinjiang, but publications and related information are too limited to allow for a proper analysis ${ }^{4}$.

The Beifang site consists of two main areas excavated in 1993 and 1996 respectively ${ }^{5}$. In 1996, a considerably damaged settlement was found and, although only a few ruined walls and wooden poles had been preserved on the western side, some pottery and relevant metal objects were uncovered. Other material was collected from the area around the settlement and from the section excavated in 1993, including stone tools, pottery vessels, metal weapon-tools, beads and a jade object, interpreted as a sceptre head. The site was placed around $1000 \mathrm{BCE}$ on the basis of typological studies, since no carbon dating exams have been performed.

The same chronology has been established for the wooden residential site of Keriya Beifang, found close to the lower reaches of the Keriya River by the Sino-French investigation team at the beginning of the 2000s. Numerous objects made of pottery, stone, bronze and jade were recovered from the settlement ${ }^{6}$.

The Liushui cemetery in Yutian County is a large site consisting of sixtyfive tombs excavated between 2003 and $2005^{7}$. It can be fairly certainly placed around $1000 \mathrm{BCE}$, thanks to carbon dating and typological examinations, and has been assigned to the Late Bronze Age ${ }^{8}$.

4. Among others, the cemetery found in the desert along the Keriya river was discovered in 1993 and later excavated, although most material connected to this site was bought from dealers and other middlemen and thus its origin is quite uncertain. Moreover, little detailed information is available and images and pictures also are very few. The Sino-French archaeological team, "Outlines of the results from the archaeological excavations in the reaches of the Keriya River," Xinjiang Wenwu, no.4 (1990): 1-12; V. H. Mair and F. Cheng, "Kungang: The Making of an Imaginary Archaeological Culture," Sino-Platonic Papers, 237(2013): 15; other remains are briefly mentioned in the summary published in 1991, in Archeological Survay team of Taklamakan, "Investigations on the southern rim of Taklamakan," Xinjiang Wenwu, no.4 (1990): 1-53. Since 1990 other discoveries have been made, however they mostly dated from the Han dynasty period.

5. Zhong Riben gongtong Niya yiji xueshu kaochadui [The Sino-Japanese Joint Research of the Niya Site] Report on the investigations at the Niya site by The Sino-Japanese Joint Research team (Urumqi: Buddhist University Niya ruins academic research institution, 1999); F. Yue and Z. Yu, Investigations conducted on the remains in Niya Beifang district (Xinjiang, Mifeng County) in 1996. Kaogu, 2(1999), 11-17.

6. Qi X., Wang B. The ancient cultures in Xinjiang along the Silk Road Vol. 2. (Urumqi: Xinjiang Renmin chubanshe, 2015), 30-31; C. Debaine-Francfort, and A. Idriss, Keriya mémoires d'un fleuve șépArchéologie et civilisation des oasis du Taklamakan Mission archéologique franco-chinoise au Xinjiang [Keriya memories of a river Archeology and civilization of Taklamakan oasis French-Chinese archaeological mission in Xinjiang] (Suilly-laTour: Éditions Findakly, 2001).

7. Xinjiang Shehui Xueyuan Kaogu Yanjiusuo Xinjiangdui [Xinjiang archaeological team, Institute of Archaeology, Chinese Academy of Social Science] "Bronze Age cemetery at Liushui, Yutian County, Xinjiang," Kaogu, no. 7 (2006): 31-40.

8. Several objects from no less than 5 tombs in the Liushui cemetery were carbon dated and, as a result, four of them fall into the range $2980-2890 \mathrm{BP}$, while one is slightly later, dating to $2640 \pm 80 \mathrm{BP}$. 
The village of Zagunluke (also known as Zahongluke') in Qiemo County, was initially investigated in $1985^{10}$. However, only during the following decades was cemetery no. 1 identified $^{11}$ and its earliest stages assigned to the Bronze Age ${ }^{12}$. Actually the earliest stage, dating to around $1500 \mathrm{BCE}$ is too poorly represented to allow for study ${ }^{13}$. On the contrary, numerous objects, including glass beads, were uncovered in the burials assigned to the second stage of the cemetery, which was dated between 800 to $200 \mathrm{BCE}$ and attributed to the Late Bronze Age.

The purpose of this paper is to study the evidence from the southern rim of the Tarim Basin in greater detail than has been attempted so far, by taking an omni-comprehensive approach, including paleoenviromental surveys, typological studies on archaeological remains, metallurgical analysis and anthropological examinations. Moreover, by re-examining the information within a broader Eurasian context, this study intends to contribute to a better understanding of prehistoric interactions between various regions.

9. J. Mei, Copper and Bronze Age metallurgy in Late Prehistory Xinjiang: its cultural context and relationship with neighbouring regions. Oxford: Archeopress, 2000: 23.

10. It was first excavated in 1985, when five graves were found and then in 1989 and 1996, when two and one-hundred-and-two burials were recovered respectively. Bayingeleng menggu zizhizhou wenguansuo [Mongolia Autonomous Prefecture's Bayincolin Office for Cultural Relics Administration] "A preliminary report on the excavation of the Zagunluke cemetery in 1989," Xinjiang Wenwu, no. 2 (1999): 1-14; Xinjiang Wenwu Kaogu Yanjiusuo [Xinjiang Institute of Archaeology], "Report of the excavation of the no. 1 cemetery in Zahongluke village, Qiemo County, Xinjiang," Kaogu Xuebao, no. 1 (2003): 89-136.

11. The smaller cemetery no. 2 , officially discovered in 1996, had been severely damaged not only by ancient, but also 20th-century explorers, and at present only the report of two graves is available. Additionally, cemetery no. 2 has been dated quite late (206 BCE - 8 AD), therefore it has not been included in this paper. Xinjiang Bowuguang Kaogubu [Department of Archaeology of the Xinjiang Museum] "Preliminary report of the excavation of the no. 2 cemetery in Zahongluke, Qiemo County," Xinjiang Wenwu, no. 1, 2 (2002): 1-21.

12. The excavators divided the site into three phases according to the characteristics of the graves and on the basis of data acquired through carbon dating, which was available for seven of the graves.

13. The first phase included only one grave, M61, which was rectangular in shape with round corners and oblique walls. The human remains discovered were quite confusing, yet the archaeologists were able to identify a single body of an adult female, in a supine position, although it is not clear how the legs were placed. Grave goods unearthed in burial M61 constituted one undecorated round-bottomed $h u$ vessel, with an elongated body and high neck, and few wooden items. No metal objects were found in grave M61. 


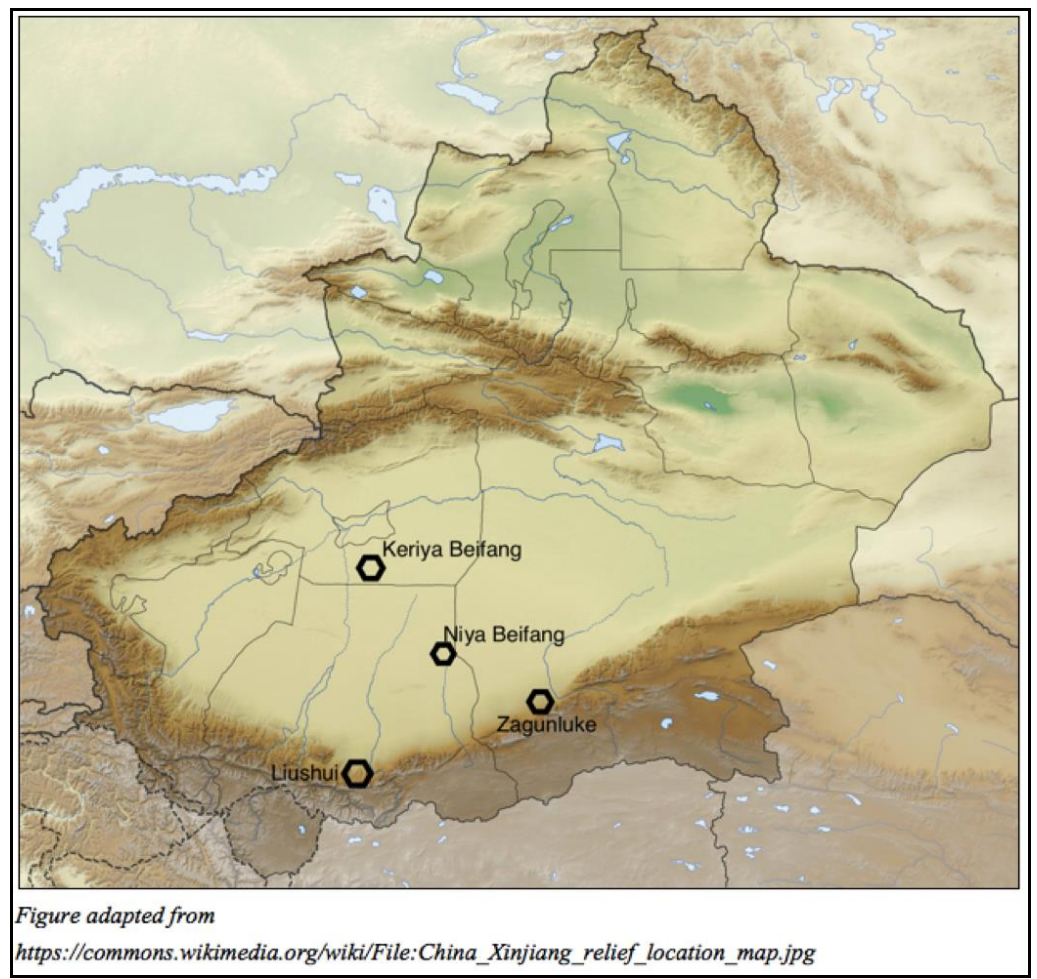

Figure 1. Map of the Sites Considered in this Paper

\section{Geographical Setting: Paleoenviroment and Paleoclimate}

The region south of the Tarim Basin spans the northern highlands of the Kunlun mountain range, from which rivers and brooks flow down to the desert and form oases on their deltas. Considering the absence of artificial irrigation systems, areas suitable for human life in the Bronze Age must have been limited to these two ecological regions, precisely the highlands and the desert oases. Indeed, remains of past human activities have been found in these environments, the former being suitable for pasturing and the latter for agropastoralist economy. It is noteworthy that several ancient sites have been recovered deep in the desert, in locations that are now too dry to be inhabited. This indicates that in the past there was some sort of water provision in these lands and, in fact, studies conducted on the ancient rivers along the southern rim of the Tarim Basin have revealed not only that rivers previously carried a larger amount of water ${ }^{14}$, but also that some of them have slowly changed their course, gradually forming their present shape ${ }^{15}$. Additionally, archaeological

14. X. Yang, Z. Liu, F. Zhang, P. D. White, and D. Wang, "Hydrological changes and land degradation in the southern and eastern Tarim Basin, Xinjiang, China." Land Degradation and Development, no. 17 (2006): 381-392.

15. Scholars have observed that, during flood seasons, water transports large quantities of sediments, which erode riverbanks and are then deposited on the riverbed. This continuous process of erosion and deposition must have caused the collapse of riverbanks and overflowing on both sides, creating new channels. See: R. Zu, Q. Gao, J. Qu, and M. Qiang "Environmental changes of oases at southern margin of Tarim Basin, China," Environmental Geology, no. 44 (2003): 639-644; X. Yang, Z. Liu, F. Zhang, P. D. White, and D. Wang, "Hydrological changes 
discoveries of crop cultivation on the lower reaches of the Keriya River, dating as early as $1000 \mathrm{BC}^{16}$, indicate the previous existence of larger green areas where there is now only desert and suggest that originally the desert might not have been as large as it is today. If wider rivers flowing in different directions did at one time exist, and the desert was significantly smaller than today, there might once have been a direct communication between the southern and northern rims of the Taklimakan Desert.

The southern rim of the Tarim Basin has experienced an arid climate and a small amount of precipitation since the early Cenozoic ${ }^{17}$. However, some studies published at the beginning of the year 2000 have shown that until 2000 BCE the humidity level was relatively high and only since then has the region become significantly more arid with minor wet oscillations ${ }^{18}$. That said, wetter conditions are more suitable for human life ${ }^{19}$ and, in fact, archaeological remains indicate that communities in Niya Beifang, Keriya Beifang, Liushui and Zagunluke were active during the humid phases.

\section{Archaeological Evidence}

Among the settlements, that found on the lower reaches of the Keriya River is better preserved than its counterpart at Niya Beifang. The former consisted of several buildings whose walls had been built using poplar poles placed in lines and some traces of fires were found inside the rooms. The roof of the buildings had been made with reeds and sheep excreta. Some form of agriculture was practiced and various grains, such as barley, have been recovered around the settlement.

and land degradation in the southern and eastern Tarim Basin, Xinjiang, China," Land Degradation and Development, no. 17 (2006): 381-392.

16. The Sino-French archaeological team, Outlines of the results from the archaeological excavations in the reaches of the Keriya River, 1997, 1-12.

17. F. Jiang, R. Hu, and H. Ma, "Studies in past climate and its possible trend in Xinjiang," Ganhanqu dili, no.1 (1998): 1-9.

18. Specifically, judging by the high $\mathrm{A} / \mathrm{C}$ range and the great presence of aquatic plants, during the period corresponding to 4000-3450 BP, the area around Niya seems to have enjoyed a humid climate. On the contrary, from 3450 to 2500 BP it was subject to more dry conditions, as demonstrated by a study conducted on the size of grains transported by the wind. Curiously, an opposite characteristic has been observed in the highlands: results of palynological analysis performed on a section of Liushui County has revealed that during the period 3500-2600 BP the highlands experienced wet conditions instead. X. Yang, Z. Liu, F. Zhang, P. D. White, and D. Wang, Hydrological changes and land degradation in the southern and eastern Tarim Basin, Xinjiang, China, 2006, 381-392; W. Zhong, H. Xiong, T. Tashpolat, Q. Shu, "The sequence of paleoenviromental changes since about $4 \mathrm{ka}$ BP, recorded by Niya section in Southern margin of Tarim Basin, Chinese," Chinese geographical science, 11, no. 2 (2001): 144-149; W. Zhong, H. Xiong, T. Tashpolat, T. Hikori, and Q. Shu, "Historical climate changes in southern Xinjiang," Journal of Geographical Sciences, 11, no. 4 (2001): 449-453; Z. Tang, G. Mu, and D. Chen, "Palaeoenvironment of mid-to late Holocene loess deposit of the southern margin of the Tarim

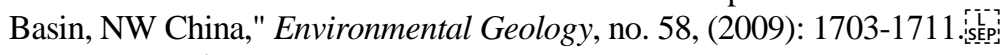

19. Ts'ui-jung Liu, "A retrospection of climate changes and their impacts in Chinese history," in Nature, Environment and culture in East Asia, ed. by C. Meinert (Leiden: Brill, 2013), 107-136. 
More information on the Bronze Age communities on the southern rim of the Tarim Basin can be acquired from the cemeteries. all the preserved graves at Liushui had surface markers and, more specifically, thirteen burials were covered by an oval or round mound, sometimes hollow on the top, while the remaining graves were fenced by a stone enclosure ${ }^{20}$. Half of the stone-fenced graves included a smaller stone enclosure on the eastern side, inside which traces of fire were found, suggesting the performance of sacrificial rites $^{21}$. Mounds covered some of the burials in the Zagunluke cemetery, but no fenced tombs were recovered there, and some graves had no marker on the surface.

Pit graves in the cemeteries of Liushui and Zagunluke were mostly rectangular with rounded corners. In Liushui they were often pointed towards the East at an angle of $10^{\circ}-20^{\circ}$ and traces of burned wood, sheep bones and pottery were recovered outside and inside the burials. Some graves contained wooden structures, the most common being wooden beds found in graves at Liushui and Zagunluke, while some burials at Zagunluke additionally included poles and funerary beds made of dog leather. In the same cemetery, many burials had a passage marked by reeds, grass and herbs, while a group labelled the 'catacomb type ${ }^{\prime 22}$ comprised entrances and corridors, suggesting a later date for these graves.

The majority of the graves contained multiple bodies ${ }^{23}$. According to anthropological evidence from the cemetery of Liushui (especially studies on pathological disorders of teeth and bones), people not only were frequent meat eaters, but also had a highly active physical life: in fact, the injuries to the lumbar and thoracic spines and other traumatic disorders in the skeletons comply with a mobile pastoralist life ${ }^{24}$. Other anthropological evidence shows that there were family relationships among individuals buried in the same grave in the Liushui cemetery ${ }^{25}$, supporting the existence of a family-based social organization within this community. A form of hierarchy might also have already been established, as suggested by some evidently richer burials, such as grave M55.

In the two cemeteries the dead were generally placed supine with high,

20. There are some very damaged burials, such as M29, M48 and M14, whose surface markers, if present, are impossible to recognize.

21. Only in grave M24 was the small enclosure on the western side.

22. Xinjiang Wenwu Kaogu Yanjiusuo [Xinjiang Institute of Archaeology], "Report of the excavation of the no. 1 cemetery in Zahongluke village, Qiemo County, Xinjiang," Kaogu Xuebao, no. 1 (2003): 89-136.

23. In the Liushui cemetery there were only eight single burials and six double graves, while the remaining tombs included more than two bodies. In the Zagunluke site more than half of the graves were multiple (55\%), while a lower number of them were single (36, 2\%).

24. J. Gresky, M. Wagner, T. H. Schmidt-Schultz, L. Schwarz, X. Wu, A. Aisha, P. E. Tarasov, and M. Schultz, "'You must keep going' - Musculoskeletal system stress indicators of prehistoric mobile pastoralists in Western China," Quaternary International, no. 405, (2016): 186-199.

25. M. Schultz, T. H. Schmidt-Schultz, and X. Wu, "Results of paleopathological and anthropological examination of human findings from the tomb 26 at Liushui, Xinjiang (China)," Eurasia Antiqua, no.13 (2007): 181-197. [ǐ 
bent $\operatorname{legs}^{26}$. As Han has stressed, this burial tradition came from the West and only rarely featured in China, where supine bodies generally had extended $\operatorname{legs}^{27}$. That said, the practice of placing supine flexed bodies was linked to the Pit Grave culture in western Asia (3300-25600 BCE) ${ }^{28}$, and the Afanasevo group in the Minusinsk Basin $(3500-2500 \mathrm{BCE})^{29}$, and was then inherited by a number of Bronze Age cultures throughout Eurasia, including the Okunev (third millennium BCE) $^{30}$, Krotov (third - early-second millennium $\left.\mathrm{BCE}\right)^{31}$ and, in Xinjiang, the Qiemu'erqieke (third - early-second millennium BCE) ${ }^{32}$. Supine bodies with moderately bent legs were found in some pre-Scythian and Scythian sites in Central Asia, in the Altai ${ }^{33}$ and the Minusinsk regions ${ }^{34}$, sometimes in combination with a few flexed remains placed on one side.

Cemeteries in southern Xinjiang were characterized by the interment of animal bones or leather accompanying human inhumation.

\section{Pottery Production}

On the southern rim of the Tarim Basin, pottery production was fairly uniform in terms of materials used. Ceramics found in the cemetery at Liushui and the settlements at Niya Beifang and Keriya Beifang were mostly sandy and red-coloured, while only a few items were made of coarse grey pottery. Judging by the quality and varying colours of the vessels, especially in the cemetery of Liushui and at the site on the Keriya River, pottery items must have been fired at low temperatures. Maybe in order to fix this problem and to hide the imperfections on the vessels, grey and red pottery objects were covered in a black layer by the Zagunluke community, a process that evidently represents a later development in ceramic technology.

Types of vessels mostly consisted of guan containers, bei cups and bo

26. However, at the Liushui site, a number of bodies were found lying on one side with bent legs, a typical practice of the Andronovo community inherited by some Scythian groups, such as the Tuvan. Y.S. Hudiakov, S.G. Skobelev, O.A. Mitko, A.Y. Borisenko, and Z. Orozbekova, "The burial rite of the early Scythian nomands of Tuva (based on the Bai-Dag I cemetery)," Archaeology Ethnology and Anthropology of Eurasia, no. 41/1 (2013): 104-113.

27. J. Han, "Different Traditions of Flexed Burials in Ancient China," Chinese Archaeology, no. 8 (2008): 170.

28. E. N. Chernykh, Ancient metallurgy in the USSR (Cambridge: Cambridge University Press, 1992), 84.

29. M. P. Gryaznov, The Afanasevo culture in the Yenisei region (St. Petersburg: Pshenitsyna), 1999.

30. M. P. Gryaznov, The ancient civilization of Southern Siberia (New York: Cowles Book Co. 1969), 52.

31. V.I. Molodin and I.A. Durakov, "Early and Middle Bronze Age burials at Ordynskoye1, Western Siberia: a new cultural interpretation," Archaeology, Ethnology and Anthropology of Eurasia, no. 41/4 (2013): 99.

32. Xinjiang Wenwu Kaogu Yanjiusuo [Xinjiang Institute of Archaeology] "Summary of excavation at Qiemu'erqieke cemetery." Wenwu, no. 1 (1981): 23-32.

33. L. T. Yablosky, "The Saka in Central Asia," in Nomads of the Eurasian Steppe in the Iron Age, ed. J. Davis-Kimball, V. A. Bashilov and L. T. Yablosky, 290. (Berekly: Zinat Press, 1995). 860-879.

34. N. Bokovenko, "The emergence of the Tagar culture," Antiquity, 80, no. 310 (2006): 
bowls, while a few $h u$ vases and pitchers were recovered from the Zagunluke cemetery alone. Guan vessels were quite widespread and despite their varying shapes, no single type prevailed, showing the existence of a rather consistent and coherent pottery production in the whole region of southern Xinjiang.

Nevertheless, it is clear that this production was influenced by neighbouring cultural groups, proving the existence of some form of connections between communities throughout Xinjiang and beyond. Excavators suggest that double-handled guan jars resembled those of the Chust culture (1300-800 BCE), however, they are also similar to the specimens found in some sites in the valleys of the Tianshan mountain range, such as in the Sidaogou site (1036-300 BCE) (Figure 2). This particular type of jars shares further similarities with some specimens found in the western region of Xinjiang, in the Kiziltur cemetery in Baicheng County (1046-476 BCE) ${ }^{35}$, and in burial M18 in the Xiabandi cemetery (900-700 BCE) in the Pamir region ${ }^{36}$. Other vessels, with rounded bottoms and elaborate carvings, were connected by archaeologists to the baskets found at the Gumugou and Xiaohe cemeteries (1800-1500 BCE) in the Lop Nur region ${ }^{37}$, while globular-shaped vases (see, for instance, the specimen in grave M1 at Zagunluke) had parallels with the stone specimens of the northern steppe culture of Qiemu'erqieke, whose later phase has been assigned to the Saka period (I millennium BCE) ${ }^{38}$.

35. Xinjiang Wenwu Kaogu Yanjiusuo [Xinjiang Institute of Archaeology] "First exploration of the Kezi'ertu'er cemetery in Baicheng County, Xinjiang," Kaogu, no. 6 (2006): 14-29.

36. Xinjiang Wenwu Kaogu Yanjiusuo [Xinjiang Institute of Archaeology] The cemetery at Xiabandi (Beijing: Wenwu chubanshe, 2012).

37. The connection was made basing on shape, style and decoration. See some examples in: Xinjiang Wenwu Kaogu Yanjiusuo [Xinjiang Institute of Archaeology] "Preliminary report of the 2003 excavation of the Xiaohe cemetery in Lop Nur, Xinjiang," Wenwu, no. 10 (2007): 442.

38. Information on the dating for Qiemu'erqieke sites have been taken from a personal conversation with Professor Kovalev in Saint Petersburg in August 2016. 

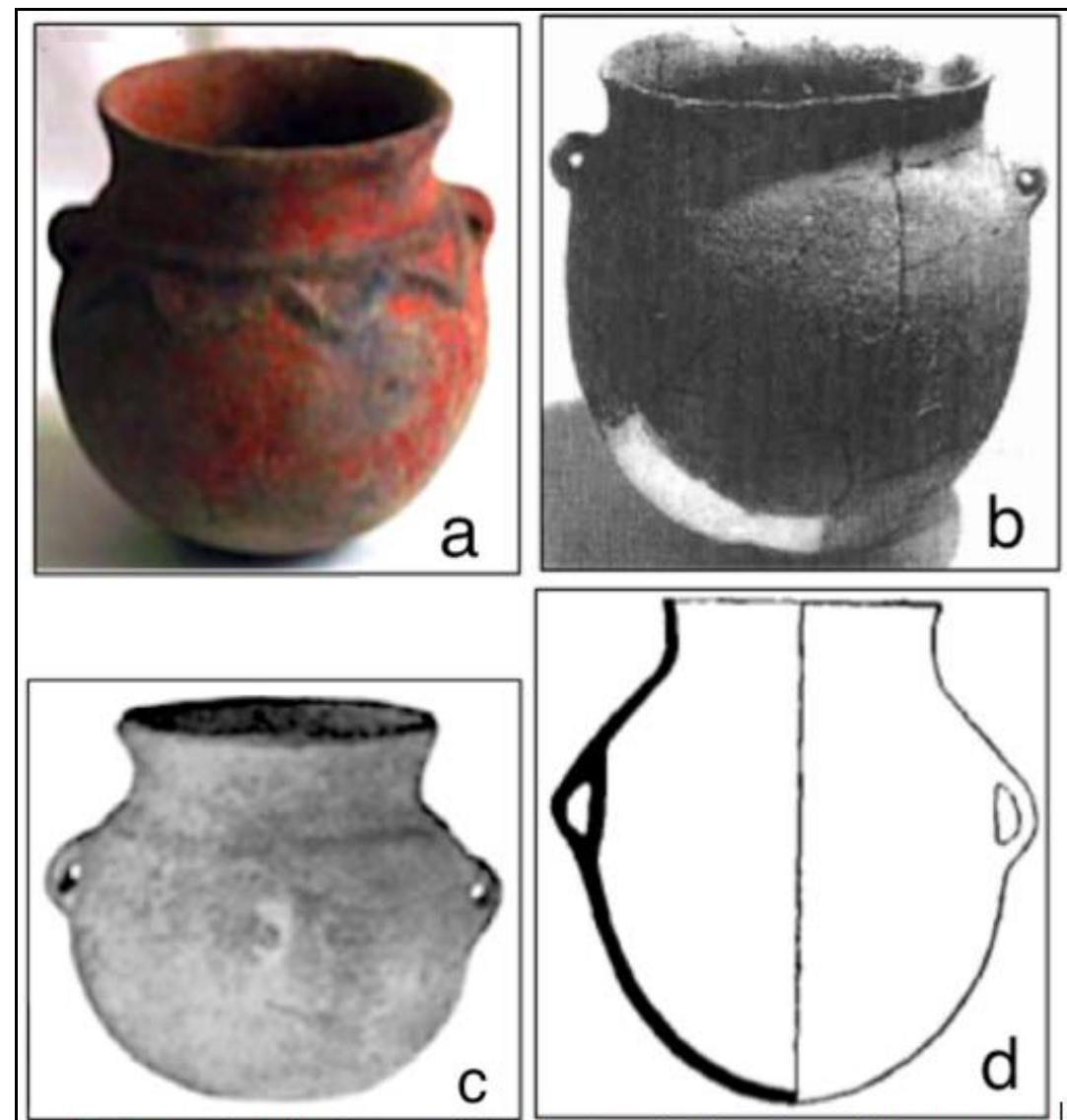

(a. after Jiang A. The Liushui Cemetery of 3000 Years Ago in the Khotan Region of Xinjiang, available on http://www.kaogu.cn/en/backup new/new/2013/1026/42232.html; b. after Yue F. and Yu Z. "Investigations conducted on the remains in Niya Beifang district (Xinjiang, Mifeng County) in 1996". Kaogu [Archaeology], no. 4 (1999): fig. 2.5; c. after Dani A. H. and Masson V. M. History of civilizations of Central Asia. The dawn of civilization: earliest times to 700 B.C. Paris: Unesco publishing, 1992: 441, fig. 5.3; d. after Xinjiang Weiyu'er Zizhiqu Wenhuating Wenwuchu [Cultural Relicts Office Xinjiang Autonomous Region] "The Sidaogou site in Mulei county, Xinjiang". Kaogu [Archaeology], no. 2 (1982): 8, fig. 2.)

Figure 2. Handled Guan Jars: a. Liushui Cemetery; b. Niya Beifang; c. Chust Culture; $d$. Sidaogou Cemetery

The type of guan jug with a flat bottom and straight walls, recovered from the Liushui cemetery and the Niya Beifang site, shared traits with those from the Neolithic sites of the Xinglongwa culture in Inner Mongolia (ca. 6000-4800 BCE), but also with more recent specimens recovered in Hebei in the Lower Xiajiadian cultural region, especially in connection with the variants of Yaowangmiao and Datuotou (ca. 2200-1600 BCE) ${ }^{39}$. Further west, similar cylindrical vessels were found in sites assigned to the Oxus Civilization (ca. 2200-1700 BCE) ${ }^{40}$ and were also collected from the Chust cultural site of Delverzin-Tepe in Fergana (second half of the second millennium BCE) ${ }^{41}$. In the first millennium they featured along the Indus and Iranian plateaus, as

39. G. Shelach, "The Earliest Neolithic Cultures of Northeast China: Recent Discoveries and New Perspectives on the Beginning of Agriculture," Journal of World Prehistory, 14, no. 4 (2000): 363-416.

40. C. C. Lamberg-Karlovsky, "The Oxus Civilization," CuPAUAM no. 39 (2013): 21-63.

41. A. H. Dani and V. M. Masson, History of civilizations of Central Asia, The dawn of civilization: earliest times to 700 B.C. (Paris: Unesco publishing, 1992), 439-442. 
well as in Margiana, at Togolokand Gonur, as research by Sarianidi shows ${ }^{42}$. (Figure 3).

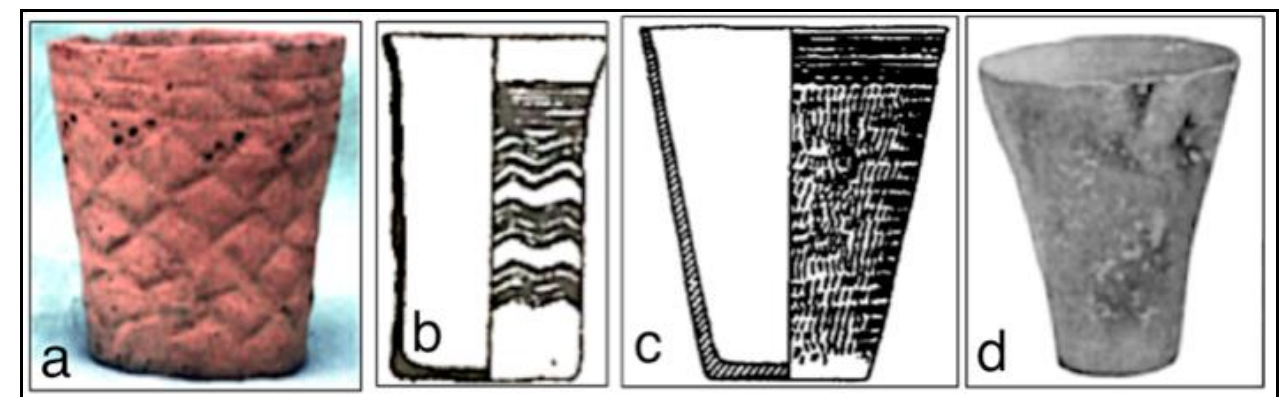

(a. after Jiang A. The Liushui Cemetery of 3000 Years Ago in the Khotan Region of Xinjiang, available on http://www.kaogu.cn/en/backup new/new/2013/1026/42232.html; b. after Yue F. and Yu Z. "Investigations conducted on the remains in Niya Beifang district (Xinjiang, Mifeng County) in 1996". Kaogu [Archaeology], no. 4 (1999): 15, fig. 7.2; c. after Shelach G. "The Earliest Neolithic Cultures of Northeast China: Recent Discoveries and New Perspectives on the Beginning of Agriculture". Journal of World Prehistory, vol. 14, no. 4 (2000): 391 fig. 10; d. after Dani A. H. and Masson V. M. History of civilizations of Central Asia, The dawn of civilization: earliest times to 700 B.C. Paris: Unesco publishing, 1992: 441, fig. 5.1).

Figure 3. Straigh-walled Guan Jugs: a. Liushui cemetery; b. Niya Beifang; c. Xinglongwa Culture d. Chust Culture

Decorations on the vessels bear similarities to steppe specimens. Indeed, most of the guan pots recovered from southern Xinjiang were carved on the upper part or on the whole body with simple triangles and lines. These geometric patterns resemble decorations on the Karasuk vessels (1200-800 $\mathrm{BCE})^{43}$ and, later, the Tagar-culture pots $(800-200 \mathrm{BCE})$, found in the Minusinsk Basin. Decorations with a bumped pattern around the neck of two specimens from the Niya Beifang site also featured on some steppe vessels, such as those from the Qiemu'erqieke cemeteries, and later, from some Scythian settlements (first millennium BCE) ${ }^{44}$. Vessels with a row of bumps around the neck surrounding a lower decoration with lines and punched patterns were recovered from the Keriya Beifang site and bear clear similarities to those of the Karasuk culture (1200-800 BCE) (Figure 4).

42. V. I. Sarianidi, "Le complexe cultuel de Togolok 21 en Margiane" ["Cultural complex of Togolok no. 21 in Margiana"], Arts Asiatiques, 41, no.1 (1986): 5-21; V. I. Sarianidi, Necropolis of Gonur (Athens: Kapon Editions, 2007).

43. S. Legrand, "The emergence of the Karasuk culture," Antiquity, 80, no. 310 (2006): 843-879.

44. Y. V. Boltryk and E. E. Fialko, "Pottery from Scythian Burial Complexes of Rogachik Barrow Massive," Stratus Plus no. 3 (2010): 294, fig. 3. 


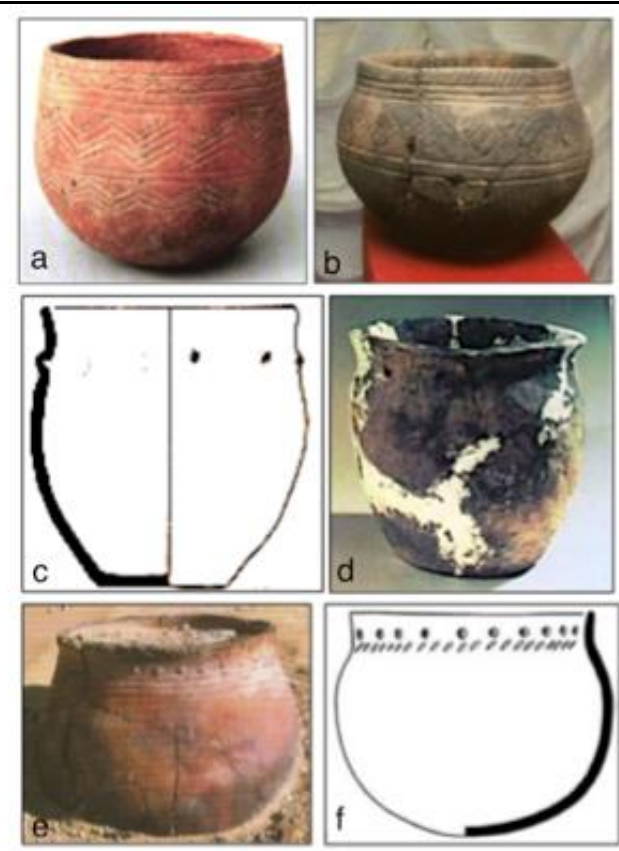

(a. aftelr Jiang A. The Liushui Cemetery of 3000 Years Ago in the Khotan Region of Xinjiang, available on http://www.kaogu.cn/en/backup new/new/2013/1026/42232.html; b. Hermitage Museum, author's picture; c. after Zhong Riben gongtong Niya yiji xueshu kaochadui [The SinoJapanese Joint Research of the Niya Site] Report on the investigations at the Niya site by The Sino-Japanese Joint Research team. Urumqi: Buddhist University Niya ruins Academic Research Institution, 1999: fig. 2.27; d. after Xinjiang Wenwu Kaogu Yanjiusuo [Xinjiang Institute of Archaeology] et al. A gran view of Xinjiang cultural relics and historic sites, China. Urumqi: Xinjiang Meishu Shejing chubanshe, 1999: 338, fig. 0949; e. after Qi X., Wang B. The ancient cultures in Xinjiang along the Silk Road Vol. 2. Urumqi: Xinjiang Renmin chubanshe 2015: 30: 5; f. after Lengrand S. "The emergence of the Karasuk culture". Antiquity, vol. 80, no. 310 (2006): 856: 13B).

Figure 4. Decorations on Pottery Vessels: a. Liushui cemetery; b. Karasuk culture; c. Nina Beifang; d. Qiemu'erqieke M16; e. Keriya Beifang; f. Karasuk site of Sukhoe Ozero II

Besides the guan pots, bei cups were also extensively recovered. Some had a flat bottom, straight, high walls and were engraved on the upper part with triangles and lines patterns. The archaeologists, who uncovered these bei cups in the sites of Niya Beifang and Liushui, have associated them to the Chust culture (1300-800 BCE), yet their distribution was as widespread as the aforementioned straight-walled guan pots. In the Zagunluke cemetery, as many as nineteen handled bei cups were recovered, mostly made of grey pottery and covered with a black layer. The shape of these receptacles varied, though they all had handles. Analogies can be drawn between these globular bei cups and items found in the Turfan Depression, in the Shuinicheng cemetery (1000-700 BCE) ${ }^{45}$, in addition to artefacts from the Delzervin site of the Chust culture (1300-800 BCE) ${ }^{46}$ and from the Sukhoe Ozero II site assigned to the Karasuk culture (1200-800 BCE), especially in terms of style

45. Xinjiang Wenwu Kaogu Yanjiusuo [Xinjiang Institute of Archaeology] "Ancient tombs in Shihezi city," Xinjiang Wenwu, no. 4 (1994): 12-19.

46. H. Shao, "Preliminary discussion on the Zagunluke culture in Xinjiang," Bianjiang kaogu yanjiu, no. 7 (2008): 170-183. 
and decoration ${ }^{47}$.

As many as fifty-one bo bowls, mostly made of grey pottery and covered in a black layer, were recovered from Zagunluke cemetery, while a relatively large quantity of these items was also found in the Liushui cemetery, globular in shape and round-bottomed specimens. The bowls in the Liushui cemetery were quite uniform in shape, but the same cannot be said of the items found in the Zagunluke site, which were more varied. In fact, despite being all roundbottomed, some bowls were globular with no distinction between the body and the neck, while others were characterized by clear shoulders and concave walls, resembling some of the items recovered from the Dalverzin site, assigned to the Chust culture $(1300-800 \mathrm{BCE})^{48}$ (Figure 5). Notably, there were handled specimens in the Zagunluke cemetery, which, on the contrary, were not found in the Liushui site. In spite of the fact the assortment of bowls taken from the Zagunluke site differed in shape, these artefacts showed no variety in decoration. In fact, while the Liushui bowls were often carved with simple designs, in Zagunluke, the bowls were not decorated at all.

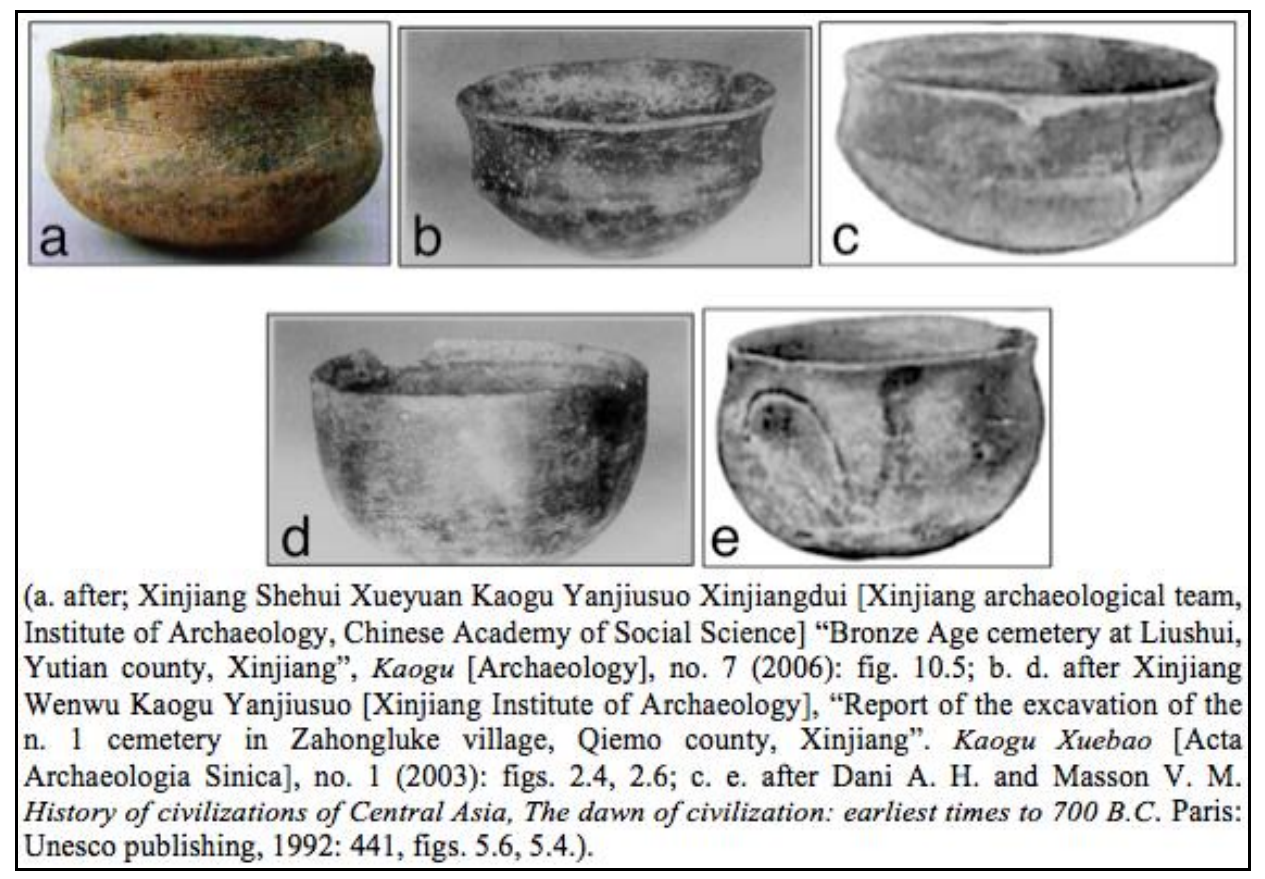

Figure 5. Bo Bowls: Specimens with Concave Walls (a. Liushui cemetery; $b$. Zagunluke cemetery 1; c. Chust culture) and with globular bowls (d. Zagunluke cemetery 1; e. Chust culture)

\section{Metallurgy}

Various types of metal objects were recovered in the region and have been split into three categories: weapon-tools, horse-related objects and personal ornaments. 843-879.

47. S. Legrand, "The emergence of the Karasuk culture," Antiquity, 80, no. 310 (2006):

48. H. Shao, Preliminary discussion on the Zagunluke culture in Xinjiang, 2008, 170-183. 
The first category comprises knives, daggers, arrowheads and socketed axes. In the Liushui, Niya and Zagunluke sites, a large quantity of knives was recovered. These knives can be divided into two groups: straight and curved blade. The first incorporates single-blade knives with no demarcation between the handle and blade. Of these knives, some of those found in the Liushui and Niya Beifang sites were longer and their blade was slightly larger than the handle, resembling those unearthed in cemetery no. 4 at Chawuhugou on the southern slope of the Tianshan mountain range. Additionally, this kind of knife was recovered in the Burgulyuk settlement in Tashkent (tenth-eighth century BCE) and from different contexts attributed to the Andronovo tradition (19001200 BCE), including the Yili-Tacheng region (Figure 6).

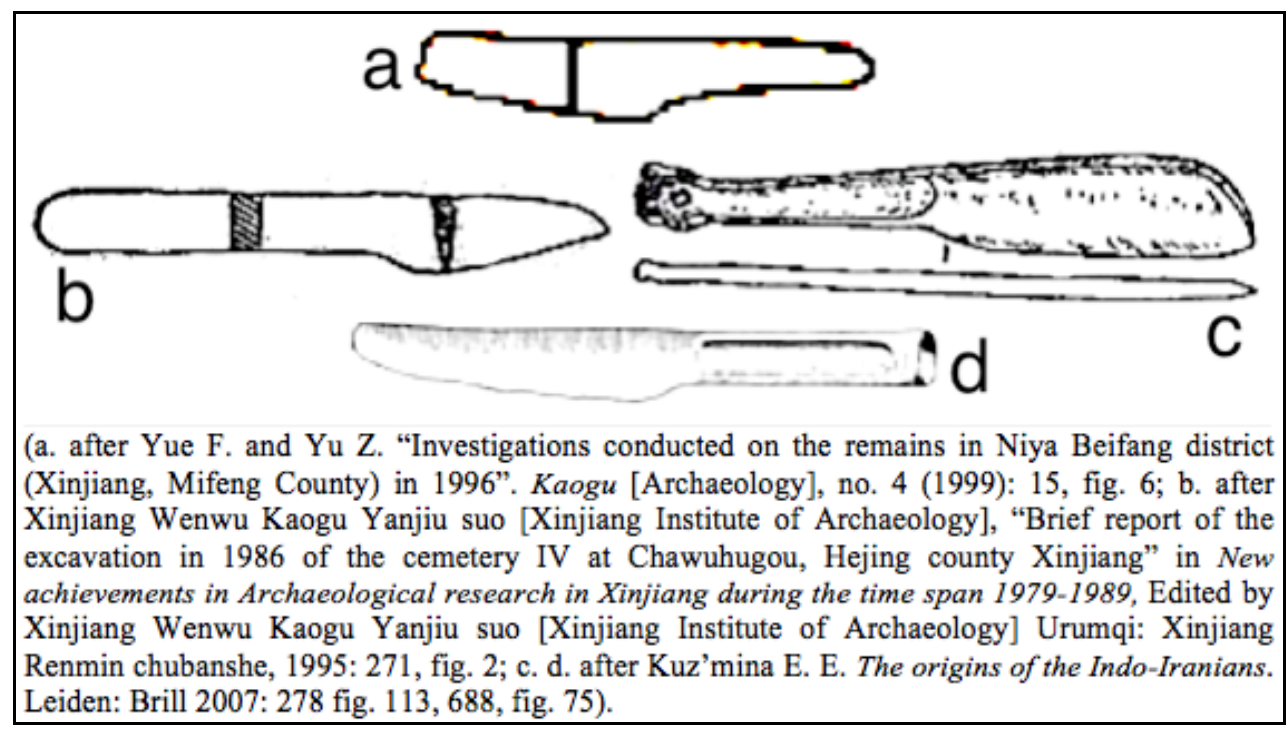

Figure 6. Curve-blade knives. A. Liushui cememtery; b. late Karasuk culture; c. Tagar culture; $d$. Tuvan type; e. Hami oasis; f. Anyang

Other knives, from the Liushui and Zagunluke cemeteries had a straight blade and, in most cases, a perforated handle (maybe for something to be inserted), making these objects perfect portable tools. Indeed, they were quite widespread among the Eurasian steppe mobile communities. In fact, a knife of this kind was found in the Qiemu'erqieke site in the Altai region ${ }^{49}$, while more numerous specimens have been recovered in many Tagar cultural sites in the Minusinsk Basin (first millennium BCE) (Figure 7). In Xinjiang, they appeared (especially from 1000 BCE onwards) in the Pamir region ${ }^{50}$, and in the Tianshan

49. Despite having long been attributed to the Bronze Age, this knife has recently been assigned to a later phase of the cemetery, corresponding to the Scythian occupation of the region (first millennium BCE). Taken from a personal conversation with Professor Kovalev in Saint Petersburg in August 2016. His studies on Xinjiang Qiemu'erqieke culture have been published in A. Kovalev, Earliest European in the heart of Asia: the Chemurchek cultural phenomen vol. 2 (Saint Petersburg: Book Antiqua, 2015).

50. In the Pamir region a broken copper knife was recovered from the Aketala hoard (around 1000 BCE). Xinjiang Wewu'er Zizhiqu Bowuguang Kaogudui [Archaeological team of Museum of Xinjiang Uygur authonomous region] "Investigation in the Neolithic sites at Aketala etc., Shufu County, Xinjiang," Kaogu, no. 2 (1977): 107-110. 
valleys, in cemeteries nos. 1 and 4 at Chawuhugou (1000-380 BCE) ${ }^{51}$. Additionally, from the same period a number of eastern specimens have been attributed to the Kayue culture in Qinghai (ca. 900-600 BCE) ${ }^{52}$.

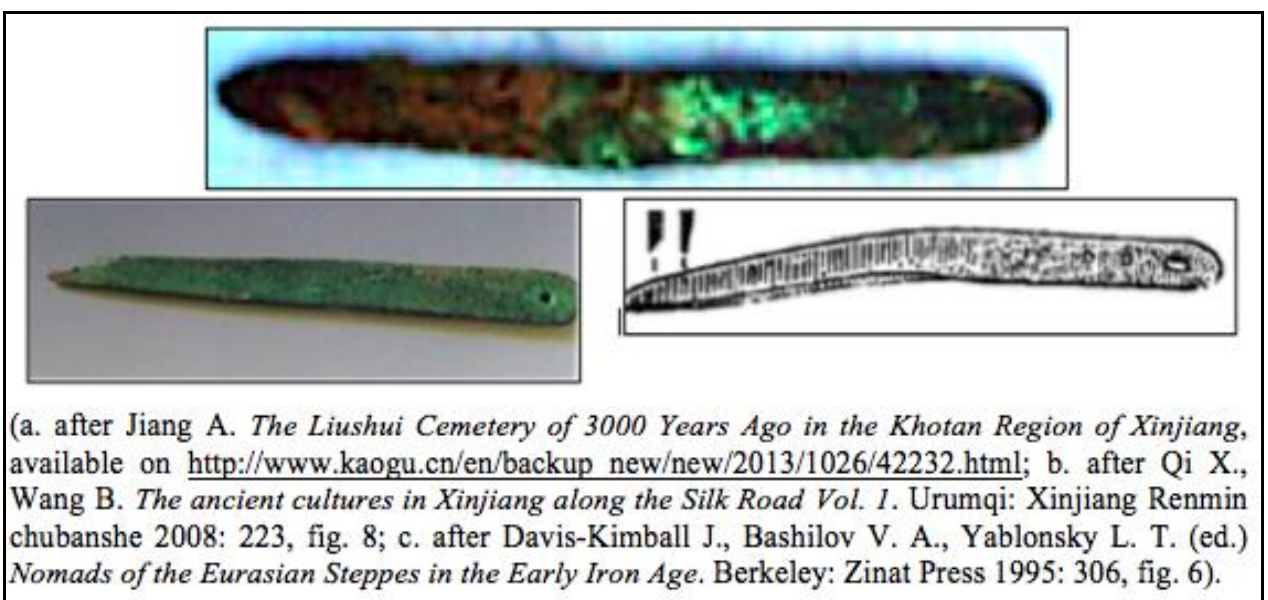

Figure 7. Straight-blade Knives with Perforated Handles: a. Liushui Cemetery; b. Qiemu'erqieke cemetery; c. Tagar Culture

The second group of knives in southern Xinjiang comprises specimens with a curved blade and with a demarcation between handle and blade. One longer knife had a decorated handle with a ring-shaped end, which, although reminiscent of specimens from the Seima-Turbino phenomenon (around 1500 $\mathrm{BCE})^{53}$, is closer to the knives of the Karasuk culture (1200-800 BCE), whose metallurgy was most likely connected to that of Seima-Turbino ${ }^{54}$. In fact, if the Karasuk people initially produced very curved knives, in the later phase of the culture they adopted a shape similar to that of the specimens found in southern Xinjiang ${ }^{55}$. It was precisely this shape that was later inherited by Scythian sub-groups, such as the Tagar and the Tuvan, which replaced the Karasuk in the Minusinsk Basin and Tuva in the first millennium $\mathrm{BCE}^{56}$.

51. Zhongguo shehui kexueyuan kaogusuo Xinjiangdui [Xinjian team of the Institute of Archaeology, Chinese Academy of Social Science] and Bayingeleng menggu zizhizhou wenguansuo [Mongolia Autonomous Prefecture's Bayincolin Office for Cultural Relics Administration] "Brief report of the excavation of the cemetery I at Chawuhugou, Hejing County Xinjiang". Xinjiang Wenwu, no. 4 (1992): 11-64; Xinjiang Wenwu Kaogu Yanjiu suo [Xinjiang Institute of Archaeology] "Brief report of the excavation in 1986 of the cemetery IV at Chawuhugou, Hejing County Xinjiang," Xinjiang Wenwu, no. 1 (1987): 1-9.

52. Museum of Huangyuan "Preliminary report of the excavation of the Kauyue culture cemetery at the village of Dahuazhong, Huanyuan County, Qinghai," Ziran Kexue shi yanjiu, no.5 (1985): 11-34.

53. The knives at Liushui and those of the Seima-Turbino community present significant differences with regard to technical and stylistic evolution, since the later specimens in Southern Xinjiang show a rougher manufacturing process and do not have zoomorphic pommels.

54. E. N. Chernykh, "Formation of the Eurasian 'Steppe Belt' of stockbreeding culture: viewed through the prism of archeometallurgy and radiocarbon dating," Archaeology Ethnology and Anthropology of Eurasia, no. 35/3 (2008): 36-53.

55. See the Karasuk knives evolution in K. Jettmar, "The Karasuk culture and its southeastern affinities," Bulletin of the Museum of Far Antiquities, no. 22 (1950): 83-126.

56. See the Tagar knives evolution in K. Jettmar, The Karasuk culture and its south- 
Curved knives with decorated and ringed handles were additionally quite widespread throughout Northern China and the Central Plain ${ }^{57}$, though most scholars agree that they must have come from the steppe ${ }^{58}$. In Xinjiang they were found in the Tianshan valleys, in the Sa'ensa'yi site (first millennium BCE) and in Hami in the Baiqi'er cemetery (eighth-third century BCE) (Figure 8).

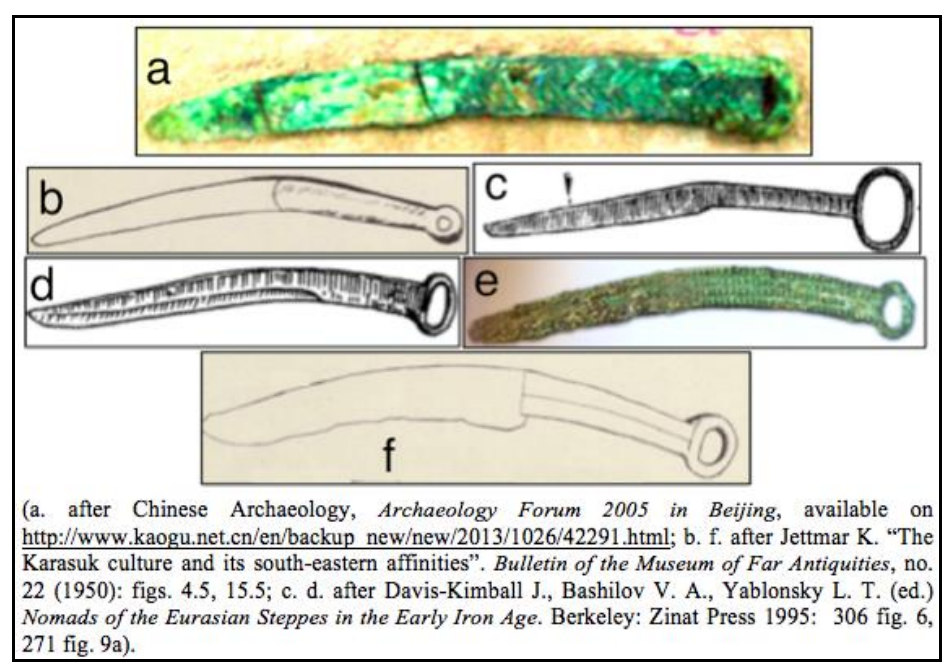

Figure 8. Curve-blade knives. A. Liushui cememtery; $b$. late Karasuk culture; c. Tagar culture; d. Tuvan type; e. Hami oasis; f. Anyang

A dagger, with a decorated ringed-handle and a rhomboid blade, was recovered from the Keriya Beifang settlement. This artefact is similar to those found in Tagar cultural sites, regarded as an evolution of the daggers produced by the Karasuk population, which in turn had evolved from the (few)

eastern affinities, 1950, 83-126. For information on the Tuvan knives see: N. A. Bokovenko, "Tuva During the Scythian Period," in Nomads of the Eurasian Steppe in the Iron Age, ed. J. Davis-Kimball, V. A. Bashilov and L. T. Yablosky (Berekly: Zinat Press, 1995), 299-314.

57. Some well manufactured curved knives were recovered from the Yanshi Erlitou cultural site, which has been dated as early as the second millennium (Zhongguo kexue yuan kaogu yanjiusuo [Institute of Archaeology, Chinese Academy of Social Science] "Brief report on the excavation of sectors 3 and 8 at Erlitou Yanshi," Kaogu no.5 (1975): 302-309), while other specimens were uncovered in the Shanrong Buluo cemetery near Beijing, dating to eighththird century BCE (Beijingshi Wenwu yanjuisuo [Beijing Academy of Cultural Relics] Shanrong wenhua kaogudui [Shan Rong Cultural Archaeological Team] "Report on the excavations at the cemetery of Shanrong Buluo, in Yanqing Juduoshan, Beijing, dating to the Estern Zhou," Wenwu, no. 8 (1989): 17-43) and in Anyang, where appreciation for this shape has been demonstrated by the discovery not only of bronze items, but also of jade pendants shaped precisely like these knives (K. Jettmar, "Cultures and ethnic groups west of China in the second and first millennium BC". Asian Perspectives, vol. 24, no. 2 (1981): 145-162; C. Baumer, The History of Central Asia: The Age of the Steppe Warriors (New York: I. B.Tauris, 2012): 152).

58. K. M. Linduff, "The Emergence and Demise of Bronze-using Cultures Outside the Central Plain in Ancient China," in The Bronze Age and Early Iron Age Peoples of Eastern Central Asia, ed. V. Mair. Washington, DC: The Journal of Indo-European Studies/The University of Pennsylvania Museum of Archaeology and Anthropology, Monograph Series, 1998: 619-646. 
Andronovo or Okunev types ${ }^{59}$. Besides the Minusinsk Basin, where the Tagar community settled, these daggers were widely distributed throughout Scythian territories, especially in the region of Tuva as well as in the Altai, Mongolia, Kazakhstan, in Uzbekistan, and in the western Pamir region (Figure 9).

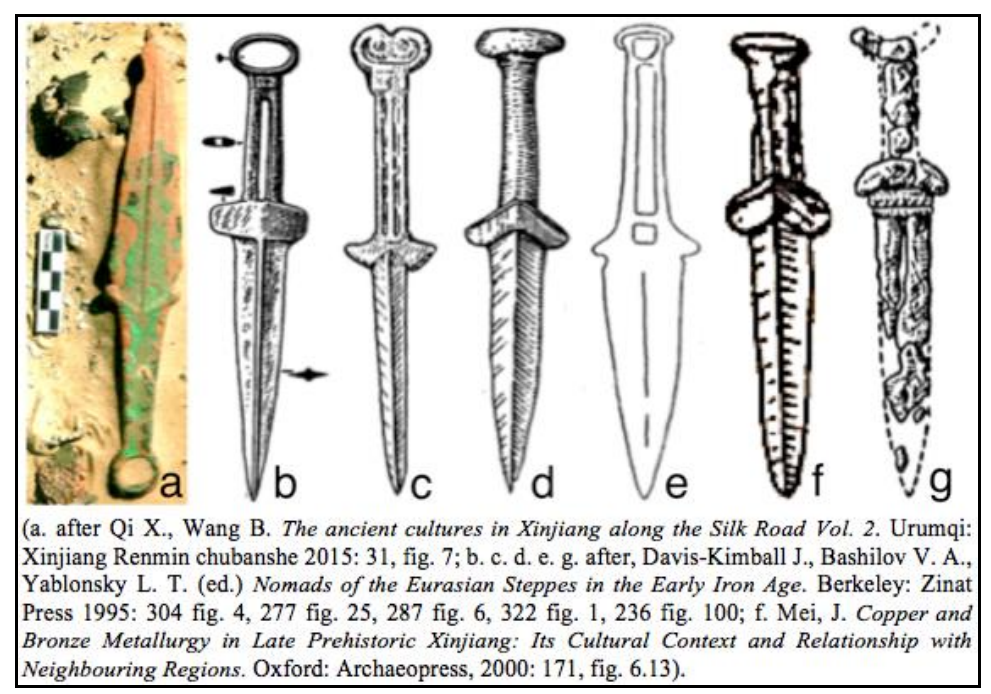

Figure 9. Daggers: a. Keriya Beifang; b. Tagar Culture; c. Tuva; d. Altai; e. Mongolia; f. Saka Culture; g. Cemetery of Tamdinsky in the Western Pamir Region

With regard to arrowheads, the specimens found in the Liushui cemetery and in the Keriya Beifang settlement, with a shaft socket and a side hook, are the most interesting, as they are analogous to the arrowheads featuring among the Scythian remains in North Caucasus, on the Volga River and in the southern Urals region $^{60}$, in addition to territories further east, in Central and Eastern Kazakhstan and southern Siberia, where they were found in correspondence to Tagar cultural sites (800-200 BCE). Around the first millennium in Xinjiang, identical hooked arrowheads, albeit made of wood, were recovered from the Subeixi site, while bronze specimens featured in the Tianshan valleys at the cemeteries of Nu'erjia and Sangongxian in Changji and the Sa'ensa'yi site, near Urumqi (Figure 10).

59. E. N. Chernykh, Ancient metallurgy in the USSR (Cambridge: Cambridge University Press, 1992), 184, fig. 5.

60. J. Davis-Kimball, V. A. Bashilov, L. T. Yablonsky, (ed.) Nomads of the Eurasian Steppes in the Early Iron Age (Berkeley: Zinat Press 1995), 14, 107. 


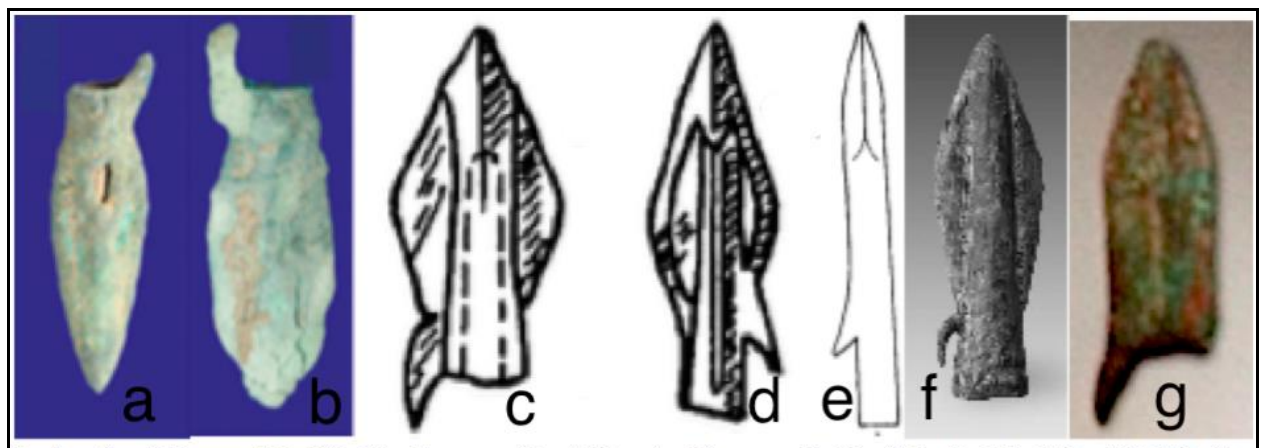

(a. b. after Wagner M., Wu X., Tarasov P., Aisha A., Ramsey C. B., Schultz M., Schmidt-Schultz T. and Gresky J. "Radiocarbon-dated archaeological record of early first millennium B.C. mounted pastoralists in the Kunlun Mountains, China". PNAS, vol. 108, no. 38 (2011): 15734, fig. 2; c, d after Davis-Kimball J., Bashilov V. A., Yablonsky L. T. (ed.) Nomads of the Eurasian Steppes in the Early Iron Age. Berkeley: Zinat Press 1995: 303, fig. 3; fig. e. after Tulufan diqu Bowuguan [Turfan Museum] "Remains and cemetery at Subeixi, in Shanshan county, Xinjiang". Kaogu [Archaeology], no. 6 (2002): 55, fig. 19.4; f. after Xinjiang Wenwu Kaogu Yanjiusuo [Xinjiang Institute of Archaeology] "Preliminary report of the 2012 excavations of the cemetery at Nu'erjia in Changjil county, Xinjiang”. Wenwu [Cultural Relics], no. 12 (2013): 34, fig. 4; g. after Xinjiang Wenwu Kaogu Yanjiusuo [Xinjiang Institute of Archaeology] The cemetery of Sa'ensa'yi. Beijing: Wenwu chubanshe, 2013: fig. 17.4).

Figure 10. Arrowheads: $a, b$. Liushui cemetery; $c$, d. Tagar Culture; e. Subeixi (wood); $f$. Nu'erjia cemetery M29A; g. Sa'ensa'yi cemetery M19

Bronze socketed celt-spades with two lateral loop-holes were found in the settlement at Niya Beifang and in the Liushui cemetery. The early production of these objects can be traced back to the Timber Grave culture (ca. 1900$1200 \mathrm{BCE}$ ); they were later unearthed in the Seima cemetery of the SeimaTurbino phenomenon (around $1500 \mathrm{BCE}$ ) and, as a result of still unclear interactions between the two communities ${ }^{61}$, they were found in some sites in Qinghai attributed to the Qijia culture (ca. 2300-1700 BCE). This kind of celt-spade was very common in the Minusinsk Basin during the Karasuk occupation (1200-800 BCE), and, centuries later, was still used by the Scythian community of Tagar (800-200 BCE) (Figure 11).

61. For further information on these contacts see: J. Mei, "Qijia and Seima-Turbino: the question of early contacts between Northwest China and the Eurasian steppe," The Bulletin of the Museum of the Far Eastern Antiquities, no. 75 (2003): 31-54. 


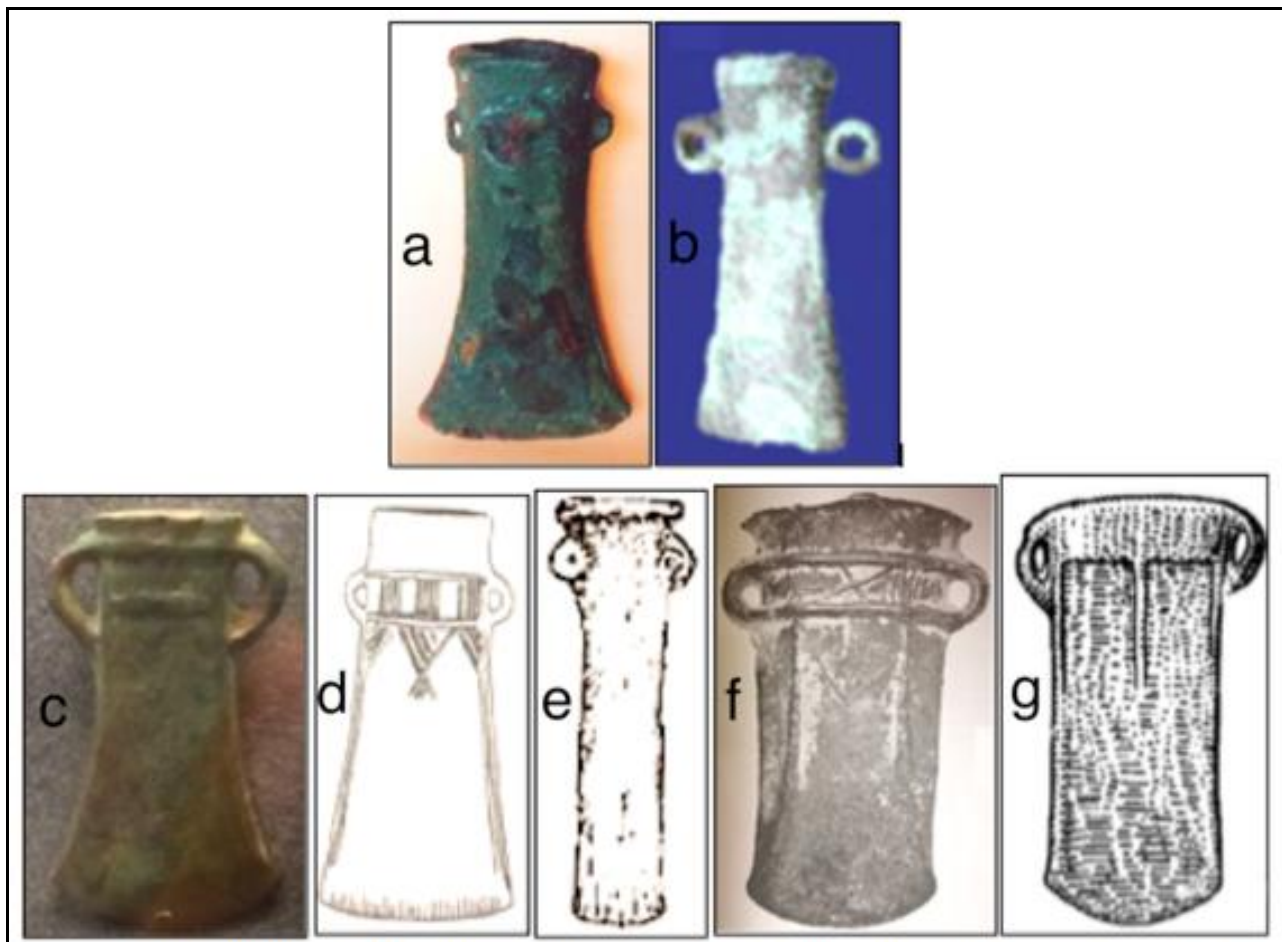

(a. after Qi X., Wang B. The ancient cultures in Xinjiang along the Silk Road Vol. 1. Urumqi: Xinjiang Renmin chubanshe 2008: 57, fig. 4.; b. after Wagner M., Wu X., Tarasov P., Aisha A., Ramsey C. B., Schultz M., Schmidt-Schultz T. and Gresky J. "Radiocarbon-dated archaeological record of early first millennium B.C. mounted pastoralists in the Kunlun Mountains, China". PNAS, vol. 108, no. 38 (2011): 15734, fig. 2; c. Hermitge Museum, author's picture; d. after Gimbutas M. "Borodino, Seima and their contemporaries". Proceeding of Prehistoric Society, no. 22 (1956): 153, fig. 9; e. after Mei, J. Copper and Bronze Metallurgy in Late Prehistoric Xinjiang: Its Cultural Context and Relationship with Neighboring Regions. Oxford: Archaeopress, 2000: 166, fig. 6.4; f. after Gryaznov M. P. The ancient civilization of Southern Siberia. New York: Cowles Book Co. 1969: 54, fig. 18; g. after Davis-Kimball J., Bashilov V. A., Yablonsky L. T. (ed.) Nomads of the Eurasian Steppes in the Early Iron Age. Berkeley: Zinat Press 1995: 307, fig. 8).

Figure 11. Celt-spade with Side-loops: a. site of Niya Beifang; b. Liushui Cemetery; c. Timber Grave Culture; d. Seima Turbino horizon; e. Qijia Culture; f. Karasuk Culture; g. Tagar Culture

Regarding horse-related objects, of particular interest are the horse bridles found in the Liushui cemetery, which represent one of the earliest pieces of evidence of horse domestication in southern Xinjiang. The bridles had a stirrup-shaped end and, according to Yablonsky ${ }^{62}$ and Vishnevskaya ${ }^{63}$, it was precisely this type of bridle that in the ninth to eighth century BCE replaced bone or horn cheek pieces in Central Asia. Additional studies by the Russian academy have revealed that, after spreading throughout the

62. L. T. Yablosky, "The Saka in Central Asia," in Nomads of the Eurasian Steppe in the Iron Age, ed. J. Davis-Kimball, V. A. Bashilov and L. T. Yablosky. Berekly: Zinat Press, 1995: 305.

63. Vishnevskaya by using the holes at the end of the mouth-pieces as a criterion, established that bridles with a stirrup-shape end appeared from the eighth century BCE. O. A. Vishnevskaya, "Central Kazakhstan, Steppes in the Asian region of the USSR in ScythoSarmatian Time," Archaeology of the USSR (1990). 
Eurasian territory for two centuries, the stirrup-ended bridles were replaced by a new single-holed bridle in the sixth century $\mathrm{BCE}^{64}$. That said, the kind of bridles discovered in the Liushui cemetery was commonly found in Scythian sites in Central Kazakhstan where the Tasmola sub-group of the Saka settled, in Tuva, and also in the Minusinsk Basin, the Pamir region and southern Siberia, corresponding to sites assigned to the Tagar culture. In Xinjiang, such bridles were uncovered in contexts dating to the first millennium, on the southern slope of the Tianshan Mountains and in the Turfan Depression (Figure 12).

Bronze ornaments including earrings, rings, bracelets and a mirror, were accompanied by other ornaments made of gold.

With regard to bronze items, a mirror was recovered from the Liushui cemetery. It was round in shape with a central handle, which was decorated, though the pattern was unclear. This specimen is of a type frequently found not only in Eastern Xinjiang, (in the cemeteries of Yanbulake ${ }^{65}$, Tianshan Beilu ${ }^{66}$ and $\mathrm{Wupu}^{67}$ ), but also further east, where these objects were circulating as early as the third millennium in Gansu and Qinghai, in association with the local culture of Qijia (ca. 2300-1700 BCE) ${ }^{68}$. Although different scholarly opinions support a northern and western origin of these mirrors ${ }^{69}$, the early date of the Qijia culture has suggested that they originated in the region of present-day Gansu and Qinghai and only later spread westward throughout Xinjiang and

64. N. L. Chlenova, "Tagar Culture, Steppe Line of Asian Part of the USSR in the ScythoSarmatian Time." Archaeology of the USSR (1992): 215.

65. Xinjiang weiwu'er zizhi wenhua ting wenwuchu [Xinjiang Uygur Autonomous Region Cultural Department Cultural Relics Office] and Xinjiang daxue lishixi wenbi yu bu zhuanxiuban [Department of History, Xinjiang University], "The cemetery at Yanbulake in Hami, Xinjiang," Kaogu Xuebao, no. 3 (1989): 329-362.

66. Hami Bowuguan, Treasures of Hami (Beijing: Wenwu chubanshe, 2013), 36.

67. G. Chen, "Preliminary discussion on the ancient cultures in Xinjiang," Zhongya Xuekan, no. 4 (1995): 5-72.

68 Mirrors were recovered in Qijia cultural sites of Gamatai and Huoshaogou. (see: S. Li "The Regional Characteristics and Interactions Between the Early Bronze Metallurgies of the Northwest and Central Plains," Chinese Archaeology, 6, no. 1 (2006): 132-139; J. Mei, Copper and Bronze Metallurgy in Late Prehistoric Xinjiang: Its Cultural Context and Relationship with Neighboring Regions, 2000, 127). These mirrors were also found in correspondence to sites assigned to the cultures of Kayue (900-600 BCE) and Shajing (around 1000 BCE) in Qinghai (see: Museum of Huangyuan, "Preliminary report of the excavation of the Kauyue culture cemetery at the village of Dahuazhong, Huanyuan County, Qinghai," Ziran Kexue shi yanjiu, no. 5 (1985): 11-34; X. Xu, and S. Ge "On the types and periods of Kayue culture," Qinghai Wenwu, no. 1 (1988): 35-44).

69. Y. Lin, "A reexamination of the relationship between bronzes of the Shang culture and of the Northern Zone," in Studies of Shang Archaeology, ed. K. C. Chang (New Heven and Conn: Yale University Press 1986), 237-273; K. M. Linduff, "Zhukaigou, steppe culture and the rise of Chinese civilization," Antiquity, 69, no. 262 (1995): 133-145; K. M. Linduff, "Here Today and Gone Tomorrow: The Emergence and Demise of Bronze Producing Culture Outside the Central Plain," Integrated Studies of Chinese Archaeology and Historiography, no. 4 (1997): 393-428; K. M. Linduff, "A Walk on the Wild Side: Late Shang Appropriation of Horses in China," in Prehistoric steppe adaptation and the horse, ed. M. Levine, C. Renfrew, K. Boyle (Oxford: Oxbow, 2003), 139-162; E. E. Kuz'mina, The origins of the Indo-Iranians (Leiden: Brill 2007), 263. 
Central $\mathrm{Asia}^{70}$. This is plausible, since the abundance of round mirrors in early western China indicates that they were important objects for local cultural groups and, at the same time, suggests that they originated in this region.

Compared to the bronze personal ornaments, more interesting are the specimens made of gold, which were found in the Liushui cemetery. Besides a gold-foil pectoral (linked to the Scythian world ${ }^{71}$ ), four gold-cast earrings were recovered from grave M10. They were characterized by a circle with a biconical end: a style that might have originated from Scythian communities ${ }^{72}$. Earrings of this kind have frequently been discovered along the Amu Darya, and in the region of Tuva ${ }^{73}$. Throughout the Altai region they were also quite widespread on the south-western slope of the range, where they were recovered from the cemeteries in Suke'erte (Fuyun County) and Dongtalede (Abahe County), both dating back to after the eighth century BCE. The four gold earrings in the Liushui cemetery were found in a male grave, a custom that is close to that of the Scythians ${ }^{74}$. Interesting earrings found in the cemetery at Yanbulake, in Eastern Xinjiang, were circular in shape with a biconical end, which was created by the interlacing of two wires. Although the resulting design of the earring is close to those from the Liushui cemetery, the latters show a much more advanced technology and refined manufacturing process. Similar, but more elegant, specimens were recovered from the Iron Age stage of the Chaiwupu site (around $1000 \mathrm{BCE}$ ), near Urumqi (Figure 13).

70. X. Song, "Ancient Chinese mirrors in China and related questions," Kaogu Xuebao, no. 2 (1997): 147-169.

71. The most famous example, although later, is the pectoral from Tolstaya Mogila, found in the Ukrainian steppe (see: M. Vidale, "Gold and time, searching for new productive relationships in the evolution of the Scythian goldworking," in Gold of the Steppe Riders, Collections from Ukrainian Museums, ed. by G. L. Bonora and F. Marzatico (Milano: Silvana editore, 2007), 255, fig. 1). The eastward expansion of Scythian objects is demonstrated by the discovery of a gold foil pectoral among the Scythian remains in Tuva and, further east, in the cemetery at Jundushan, near Beijing (8th-3th century). N. A. Bokovenko, "Scythan culture in the Altai mountains," in Nomads of the Eurasian Steppe in the Iron Age, ed. by J. DavisKimball, V. A. Bashilov and L. T. Yablosky (Berekly: Zinat Press, 1995), 288, fig. 10c; Beijingshi Wenwu yanjuisuo [Beijing Academy of Cultural Relics] Shanrong wenhua kaogudui [Shan Rong Cultural Archaeological Team], Report on the excavations at the cemetery of Shanrong Buluo, in Yanqing Juduoshan, Beijing, dating to the Estern Zhou, 1989, 17-43.

72. J. Davis-Kimball, V. A. Bashilov, and L. T. Yablonsky, (ed.) Nomads of the Eurasian Steppes in the Early Iron Age (Berkeley: Zinat Press 1995), 218, 230, 288.

73. On the Amu Darya they were found in the Uigarak cemetery and at the site on the Sakar Choge. See: hills B. Armbruster,"Gold technology of the ancient Scythians - gold from the kurgan Arzhan 2, Tuva," ArcheoSciences, no. 33 (2009): 187-193.

74. However, each Scythian male body was matched with only one single earring. L. T. Yablosky, The material culture of the Saka and historical reconstruction, 1995, 218. 


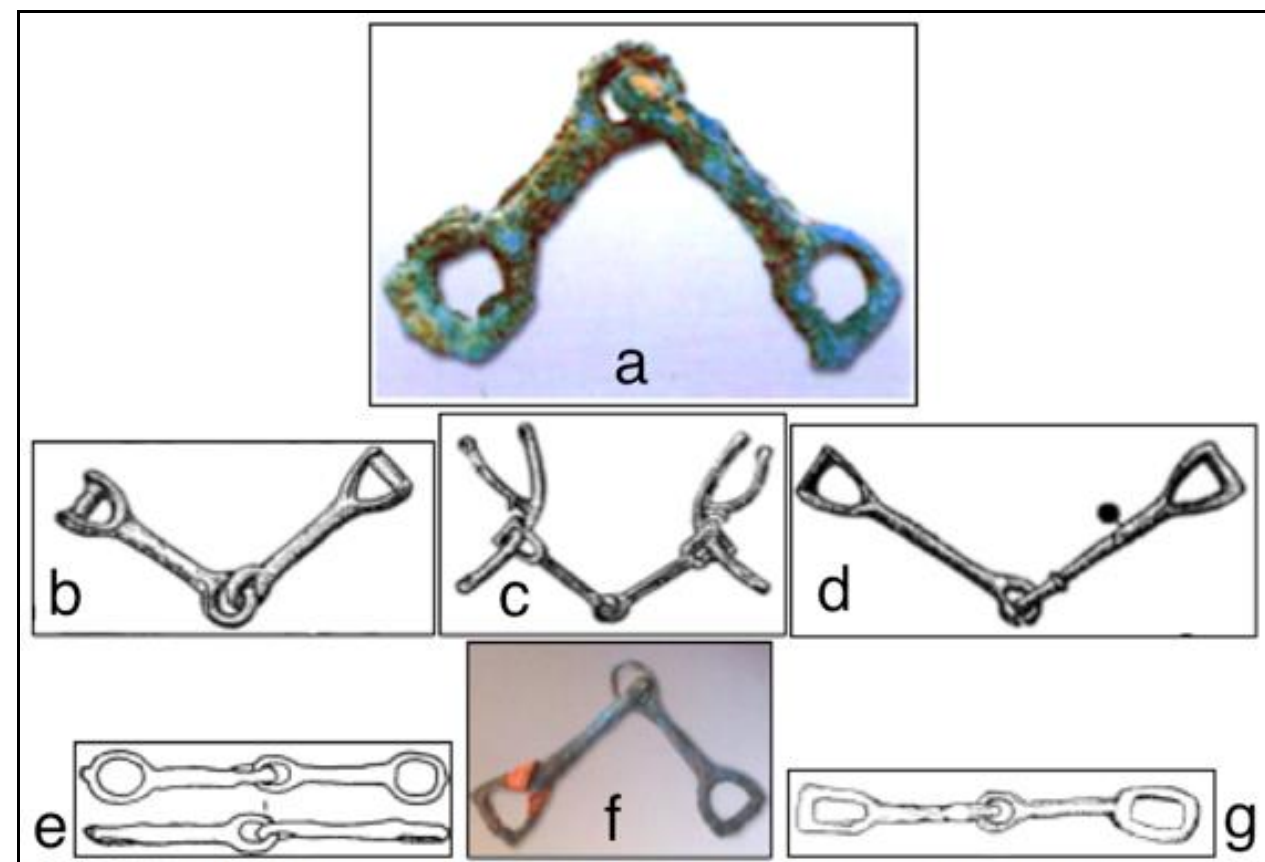

(a. after Xinjiang Shehui Xueyuan Kaogu Yanjiusuo Xinjiangdui [Xinjiang archaeological team, Institute of Archaeology, Chinese Academy of Social Science] "Bronze Age cemetery at Liushui, Yutian County, Xinjiang", Kaogu [Archaeology], no. 7 (2006): fig. 10.6; b. c. d. after DavisKimball J., Bashilov V. A., Yablonsky L. T. (ed.) Nomads of the Eurasian Steppes in the Early Iron Age. Berkeley: Zinat Press 1995: 204 fig. 5, 270 fig. 8, 307 fig. 11; e. after Zhongguo shehui kexueyuan kaogusuo Xinjiangdui [Xinjiang team of the Institute of Archaeology, Chinese Academy of Social Science] and Bayingeleng menggu zizhizhou wenguansuo [Mongolia Autonomous Prefecture's Bayincolin Office for Cultural Relics Administration], "Brief report of the excavation of the cemetery I at Chawuhugou, Hejing county Xinjiang". Xinjiang Wenwu [Xinjiang Cultural Relics], no. 4 (1992): 91, fig. 14.7; f. after Xinjiang Wenwu Kaogu Yanjiusuo [Xinjiang Institute of Archaeology] The cemetery of Sa'ensa'yi. Beijing: Wenwu chubanshe, 2013: fig. 7.3; g. Tulufan diqu wenwuju [Office for Cultural Relics of Turfan] "Report on the excavation at the Yanghai cemetery in Shanshan County, Xinjiang". Kaogu Xuebao [Acta Archeologia Sinica], no. 11 (2011): fig. 12.3).

Figure 12. Horse Bridles: a. Liushui Cemetery; $b$. Tasmola Group; c. Arzhan Cemetery in Tuva; d. Tagar Culture; e. Tianshan Valleys: Chawuhugou Cemetery no. 1 M1; f. Tianshan Valleys: Sa'ensa'yi Cemetery M6; g. Turfan Depression: Yanghai Site 


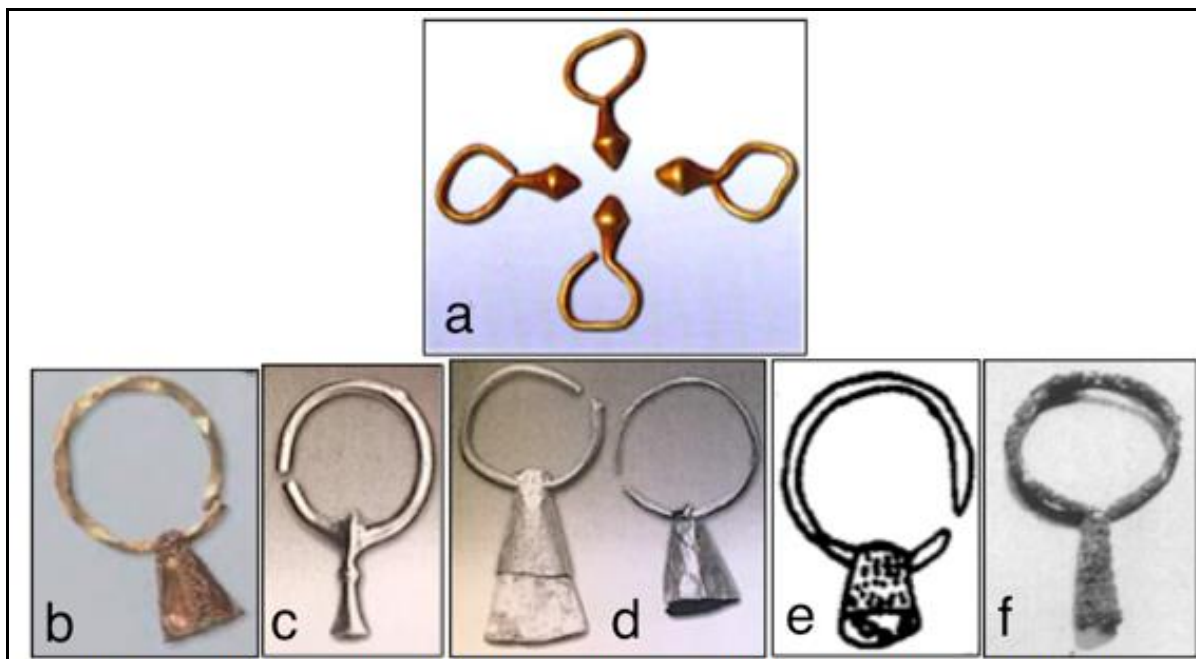

(a. after Xinjiang archaeological team, Institute of Archaeology, Chinese Academy of Social Science] "Bronze Age cemetery at Liushui, Yutian county, Xinjiang", Kaogu [Archaeology], no. 7 (2006): fig. 10.3; b after Chinese Archaeology, Archaeology Forum 2005 in Beijing, available on http://www.kaogu.net.cn/en/backup_new/new/2013/1026/42291.html; c. d. after Xinjiang Wenwu Kaogu Yanjiusuo [Xinjiang Institute of Archaeology] Collection of archaeological and historical works on the Altai district. Beijing: Wenwu chubanshe 2015: figs 13.3, 39.1; e. Xinjiang Wenwu Kaogu Yanjiusuo [Xinjiang Institute of Archaeology] "Report on the excavation of the Chaiwupo cemetery in Urumqi". Xinjiang Wenwu [Xinjiang Cultural Relics], no. 1 (1998): 23, fig. 11.12; f. Xinjiang weiwu'er zizhi wenhua ting wenwuchu [Xinjiang Uygur Autonomous Region Cultural Department Cultural Relics Office] and Xinjiang daxue lishixi wenbi yu bu zhuanxiuban [Department of History, Xinjiang University] "The cemetery at Yanbulake in Hami, Xinjiang". Kaogu Xuebao [Acta Archeologia Sinica], no. 3 (1989): fig. 12.11).

Figure 13. Earrings: a. Liushui Cemetery; b. Cemetery of Arzhan in Tuva; c. Suke'erte Cemetery (Altai); d. Dongtalede cemetery (Altai); e. Chaiwupu site; f. Specimen from Yanbulake Cemetery

\section{Discussion}

Remains assigned to the Bronze Age on the southern rim of the Tarim Basin are very few in number, however this analysis has shown that the highlands were inhabited by semi-nomadic communities, which practised seasonal pastoralism. Specifically, information on climate and environment indicates that this region was particularly rich in pasturages during the summer, suggesting that it was inhabited during the hot season and then abandoned as soon as the winter came. When the climate cooled, these semi-nomadic populations most likely walked down from the highlands to reach the lower lands, where settlements such as those of Niya Beifang and Keriya Beifang were located. If that is the case, it is evident that a double economy existed within these communities: while in the desert oases the discovery of various grains and several agricultural tools indicates that some form of farming was practised, the evidence from the cemeteries in the highlands demonstrates that sheep breeding was the main occupation of these communities. In fact, not only have sheep bones been widely discovered in graves accompanying the dead, but traces of their burnt remains have also been identified in tomb fillings and in mounds. Sheep were probably sacrificed in the smaller stone 
enclosure found on the eastern side of some graves in the Liushui cemetery and these funerary rituals likely involved libations, as demonstrated by the discovery of drinking horns in the Zagunluke cemetery ${ }^{75}$. Anthropological evidence also points to a mobile or semi-mobile pastoralist lifestyle for the communities of Liushui and Zagunluke. Most of the adults showed traces on their bones indicating long walks on mountain slopes and their teeth displayed typical features of meat eaters. Agriculture on the highlands was rarely practised, if at all, so it is unsurprising that only a few tools that might have in some way been connected with agricultural activities were found in the Liushui and Zagunluke cemeteries.

Horses had definitely been domesticated, as demonstrated by the recovery of Scythian-type bronze bridles and horn-made cheek pieces.

The existence of a hierarchical form of social organization is evident from the discovery of wealthier graves, and it was perhaps based on family clans, since there were family connections between people buried in the same grave.

If signs of the existence of some form of social organization can be found looking at the archaeological remains, there is no evidence of any organization based on labour divisions and, specifically, no indication of the existence of metallurgist clans. No tools for metal production were recovered from the graves and neither were the so-called founder hoards ${ }^{76}$. This is relevant in so far as there is no clear evidence of a local metal production, although it is quite the case, given the quantity of materials and their peculiar features, which indicate a completely acquired metallurgical knowledge.

Metal objects found in the examined sites were among the first evidence of metallurgical production in southern Xinjiang and were of the steppe variety: bronze items were of the Scythian type and, more specifically, very similar to those produced by the Tagar sub-group of Scythian communities in the Minusinsk Basin, while gold specimens showed analogies with those from the cemetery of Arzhan in Tuva. Some of the tools displayed constant similarities with specimens from the cultural sites of Qijia, Seima Turbino, Karasuk and Tagar. It is known that at one point, Seima Turbino-related populations, came into contact with the Qijia community and it is clear, from the metallurgical evidence, that they also had a great impact on the metallurgy of the Karasuk and, later, Tagar cultures.

Therefore, putting aside the debate on the connection between the Qijia and Seima Turbino communities (which, for chronological reasons, could not have directly influenced the societies in southern Xinjiang), it can be concluded

75. These objects, specifically made from ox horn and open at both ends, were used for ritual ceremonies and libations, and at the same time were symbols of supremacy - both military and social - among Scytho- Sarmatian communities. N. Manassero, "Warriors and Kings Libations: drinking horns in the Scythians ideology," in Gold of the Steppe Riders, Collections from Ukrainian Museums, ed. G. L. Bonora and F. Marzatico (Milano: Silvana editore, 2007), 220-225.

76. The founders hoards (also called the metallurgists hoards) generally included one type of objects and moulds, reflecting both the development of metallurgical technology and the appearance of a specialized group of metalworkers. E. E. Kuz'mina, The origins of the IndoIranians (Leiden: Brill 2007), 97. 
that, around the first millennium BCE, two cultural groups produced types of metal objects extraordinarily similar to those found on the southern rim of the Tarim Basin and they were precisely the Karasuk and the Tagar in the Minusinsk Basin. That said, such a large quantity of metal objects, as that found in southern Xinjiang, is unlikely to represent a form of gift-exchange practice, so it is convincing enough that these items were made locally. Given that metallurgical production requires the transfer of the technological package, it seems reasonable to speculate that among the Tagar groups that occupied the Minusinsk Basin around the ninth century BCE, some moved south and reached the southern rim of the Tarim Basin, where they settled and began to locally produce metal objects and, according to most scholars, glass too. In fact, the production of glass, found in the cemeteries of Liushui and Zagunluke, was apparently introduced in Xinjiang by the Scythian communities, who worked materials locally, supporting the theory of a southward movement of these populations ${ }^{77}$. This hypothesis finds support from the pottery remains, many of which resemble those of the late Karasuk and early Tagar cultures, but also from anthropological evidence, which indicates that the population of Liushui had affinities with people from southern Siberia and the Black Sea. In this regard, though very few anthropological studies have been conducted on the Scythians, it has been recently suggested that this community may have originated from the Timber Grave population in the northern region of the Black Sea $^{78}$. If so, the most reasonable hypothesis is that Tagar Scythians, who had already mixed with the local Siberian population, moved south and, via the Tianshan valleys and, to some extent, Eastern Xinjiang, reached the southern region of the Taklamakan Desert. The Chärchän Man, found in Zagunluke cemetery was of Caucasoid descent, and, according to the archaeologists, he was related to the Saka people ${ }^{79}$.

77. F. Gan, H. Cheng and Q. Li, "Origin of Chinese ancient glasses: study on the earliest Chinese ancient glasses," Science in China Series E: Technological Sciences, 49, no. 6 (2006): 710 .

78X. Zhang and Zhu H. "Bioarchaeological Analysis of Bronze Age Populations of the Liushui Cemetery Using Dental Nonmetric Traits," Acta Anthropologica Sinica, 33, no. 4, (2014): 460-470; A. Juras, M. Krzewińska, G. A. Nikitin, E. Ehler, M. Chyleński, S. Łukasik, M. Krenz-Niedbała, V. Sinika, J. Piontek, S. Ivanova, M. Dabert and A. Götherström, "Diverse origin of mitochondrial lineages in Iron Age Black Sea Scythians," Scientific reports, no. 7 (2017): 1-10. In addition to these studies, eighteen skulls from the Liushui graveyard were examined and compared to specimens from western and eastern regions (specifically Volga and Anyang respectively), revealing a prevalence of western components in the craniofacial feature. An analysis of the metric traits of the same skulls was also performed, leading to an opposite conclusion. However, as the authors themselves declare in the paper, the methodology used to evaluated the metric traits is new and the necessary genetic evidence is yet to be acquired. J. Tan, et al., "Craniometrical evidence for population admixture between Eastern and Western Eurasians in Bronze Age southwest Xinjiang," Chinese Science Bulletin, 58, no. 3 (2013): 299306.

79Furthermore, the shape of the hats found in the Chärchän Man grave were of Scythian type, similar to those carved in the small Saka sculptures recovered from the counties of Xinyuan and Gongliu in the Yili-Tacheng region. D. Kamberi, "The Three Thousand Year Old Chärchän Man Preserved at Zaghunluq. Abstract Account of a Tomb Excavation in Chärchän County of Uyghuristan," Sino-Platonic Papers, 44 (1994): 1-15. X. Qi, and B. Wang, The 
The remains in Southern Xinjiang show some analogies with Eastern Xinjiang, as well as with the Chust culture, especially concerning the round mirror, some pottery vessels and stone tools. Even though the number of similar objects is low, it is safe to affirm that connections among communities living in these regions had already been established.

\section{Conclusion: New Challenges and Future Research Directions}

The homogeneity of the remains in the three sites indicate the existence of a consistent single cultural group, which occupied the whole area of southern Xinjiang and was involved in developing mobile pastoralism in Northwest China. These people were very much connected to the northern Scythian communities, however despite the similarities revealed by archaeological and anthropological evidence, how and to what extent these people from Siberia reached the southernmost region of the Tarim Basin is still to be conclusively determined. For now, remains specifically similar to those of the Tagar group and to those found in southern Xinjiang have been recovered from several Iron Age sites in the Tianshan valleys, suggesting that, from the north, Scythians moved to the valleys of the Tianshan Mountain range before arriving in Liushui, Beifang and Zagunluke via Pamir, Eastern Xinjiang, or, possibly, through the desert following the course of rivers that have now run dry.

A possible association with Scythian-related populations has raised questions on the assignment of the four examined sites to the Bronze Age. Especially problematic are the cemeteries of Zagunluke and Liushui. The presence of catacomb-like graves in the former, the strong similarities with Iron Age communities, such as the Tagar, and the recovery, not only of glass artefacts, typical of Iron Age products, but also of some broken iron knives in both sites, make their attribution to the Bronze Age very much questionable.

Numerous questions remain unanswered and correctly assigning these sites, as well as acquiring a proper understanding of the early societies on the southern rim of the Tarim Basin, pose future challenges for archaeological research in the region.

\section{Acknowledgments}

My thanks to Prof. Sabrina Rastelli for her methodological suggestions. I am also grateful to Professors Liu W. and Kovalev A. for having shared with me precious information on the newest discoveries in Xinjiang and its neighbouring regions.

ancient cultures in Xinjiang along the Silk Road Vol. 1 (Urumqi: Xinjiang Renmin chubanshe 2008), 254-255. 


\section{Bibliography}

Archaeological Survey Team of Taklimakan. "Investigations on the southern rim of Taklamakan." Xinjiang Wenwu, no.4 (1990): 1-53.

Armbruster B. "Gold technology of the ancient Scythians - gold from the kurgan Arzhan 2, Tuva." ArcheoSciences, no. 33 (2009): 187-193.

Baumer C. The History of Central Asia: The Age of the Steppe Warriors. New York: I. B. Tauris, 2012.

Bayingeleng menggu zizhizhou wenguansuo [Mongolia Autonomous Prefecture's Bayincolin Office for Cultural Relics Administration] "A preliminary report on the excavation of the Zagunluke cemetery in 1989." Xinjiang Wenwu, no. 2 (1999): 1-14.

Beijingshi Wenwu yanjuisuo [Beijing Academy of Cultural Relics] Shanrong wenhua kaogudui [Shan Rong Cultural Archaeological Team] "Report on the excavations at the cemetery of Shanrong Buluo, in Yanqing Juduoshan, Beijing, dating to the Estern Zhou." Wenwu, no. 8 (1989): 17-43.

Bokovenko, N. "The emergence of the Tagar culture." Antiquity, 80, no. 310 (2006): 860-879.

Bokovenko N. A. "Tuva During the Scythian Period." In Nomads of the Eurasian Steppe in the Iron Age, edited by J. Davis-Kimball, V. A. Bashilov and L. T. Yablosky. Berekly: Zinat Press, 1995.

Boltryk Y. V. and Fialko E. E "Pottery from Scythian Burial Complexes of Rogachik Barrow Massive." Stratus Plus no. 3 (2010): 289-331.

Chen G. "Preliminary discussion on the ancient cultures in Xinjiang." Zhongya Xuekan, no. 4 (1995): 5-72.

Chernykh E. N. Ancient metallurgy in the USSR. Cambridge: Cambridge University Press, 1992.

Chernykh E. N. "Formation of the Eurasian 'Steppe Belt' of stockbreeding culture: viewed through the prism of archeometallurgy and radiocarbon dating." Archaeology Ethnology and Anthropology of Eurasia no. 35/3 (2008): 36-53.

Chlenova, N. L. "Tagar Culture Steppe Line of Asian Part of the USSR in the Scytho-Sarmatian Time." Archaeology of the USSR, 1992.

Dani A. H. and Masson, V. M. History of civilizations of Central Asia, the dawn of civilization: earliest times to 700 B.C. Paris: Unesco publishing, 1992.

Davis-Kimball J., Bashilov V. A., Yablonsky L. T. (eds.) Nomads of the Eurasian Steppes in the Early Iron Age. Berkeley: Zinat Press 1995.

Debaine-Francfort C. and Idriss A. Keriya mémoires d'un fleuve Archéologie et civilisation des oasis du Taklamakan Mission archéologique franco-chinoise au Xinjiang [Keriya memories of a river Archeology and civilization of Taklamakan oasis French-Chinese archaeological mission in Xinjiang]. Suilly-la-Tour: Éditions Findakly, 2001.

Gan F., Cheng H. and Li Q. "Origin of Chinese ancient glasses: study on the earliest Chinese ancient glasses." Science in China Series E: Technological Sciences, 49, no.6 (2006): 701-713.

Gresky J., Wagner M., Schmidt-Schultz T. H., Schwarz L., Wu X., Aisha A., Tarasov P. E., and Schultz M. "'You must keep going' - Musculoskeletal system stress indicators of prehistoric mobile pastoralists in Western China". Quaternary International, no. 405, (2016): 186-199.

Gryaznov M. P. The Afanasevo culture in the Yenisei region. St. Petersburg: Pshenitsyna, 1999.

Gryaznov M. P. The ancient civilization of Southern Siberia. New York: Cowles Book Co. 1969. 
Hami Bowuguan. Treasures of Hami. Beijing: Wenwu chubanshe, 2013.

Han J. "Different Traditions of Flexed Burials in Ancient China." Chinese Archaeology, no. 8 (2008): 168-171.

Huang X., and Wu Z. "Two groups of stone remains discovered on the upper reaches of Keriya river." In New results of archaeological research in Xinjiang (19901996), edited by Xinjiang Wenwu Kaogu Yanjiusuo [Xinjiang Institute of Archaeology]. Urumqi: Xinjiang Meishu Shejing chubanshe, 1997: 44-56.

Hudiakov Y.S., Skobelev S.G., Mitko O.A., Borisenko A.Y., and Orozbekova Z. "The burial rite of the early Scythian nomads of Tuva (based on the Bai-Dag I cemetery)." Archaeology Ethnology and Anthropology of Eurasia, no. 41/1 (2013): 104-113.

Jettmar K. "Cultures and ethnic groups west of China in the second and first millennium BC." Asian Perspectives, 24 no. 2 (1981): 145-162.

Jettmar K. "The Karasuk culture and its south-eastern affinities." Bulletin of the museum of Far Antiquities, no. 22 (1950): 83-126.

Jiang F., Hu R., and Ma, H. "Studies in past climate and its possible trend in Xinjiang." Ganhanqu dili, no.1 (1998): 1-9.

Juras A., Krzewińska M., Nikitin G. A., Ehler E., Chyleński M., Łukasik S., KrenzNiedbała M., Sinika V., Piontek J., Ivanova S., Dabert M. and Götherström A. "Diverse origin of mitochondrial lineages in Iron Age Black Sea Scythians." Scientific reports, no. 7 (2017): 1-10.

Kamberi D. "The Three Thousand Year Old Chärchän Man Preserved at Zaghunluq Abstract Account of a Tomb Excavation in Chärchän County of Uyghuristan." Sino-Platonic papers, 44 (1994): 1-15.

Kovalev A. Earliest European in the heart of Asia: the Chemurchek cultural phenomenon vol. 2. Saint Petersburg: Book Antiqua, 2015.

Kuz'mina E. E. The origins of the Indo-Iranians. Leiden: Brill 2007.

Lamberg-Karlovsky C. C. "The Oxus Civilization." CuPAUAM no. 39 (2013): 21-63.

Legrand S. "The emergence of the Karasuk culture." Antiquity, 80, no. 310 (2006): 843-879.

Li S. "The Regional Characteristics and Interactions Between the Early Bronze Metallurgies of the Northwest and Central Plains." Chinese Archaeology, 6, no. 1 (2006): 132-139.

Linduff K. M. "A Walk on the Wild Side: Late Shang Appropriation of Horses in China." In Prehistoric steppe adaptation and the horse, edited by M. Levine, C. Renfrew, K. Boyle. Oxford: Oxbow, 2003.

Linduff K. M. "Here Today and Gone Tomorrow: The Emergence and Demise of Bronze Producing Culture Outside the Central Plain." Integrated Studies of Chinese archaeology and historiography no. 4 (1997): 393-428.

Linduff K. M. "The Emergence and Demise of Bronze-using Cultures Outside the Central Plain in Ancient China." In The Bronze Age and Early Iron Age Peoples of Eastern Central Asia, edited by Victor Mair. Washington, DC: The Journal of Indo-European Studies/The University of Pennsylvania Museum of Archaeology and Anthropology, Monograph Series, 1998.

Linduff K. M. "Zhukaigou, steppe culture and the rise of Chinese civilization." Antiquity, vol. 69, no. 262 (1995): 133-145.

Mair V. H. and Cheng F. "Kungang: The Making of an Imaginary Archaeological Culture." Sino-Platonic Papers, 237(2013): 1-32.

Manassero N. "Warriors and Kings Libations: drinking horns in the Scythians ideology." In Gold of the Steppe Riders, Collections from Ukrainian Museums, edited by G. L. Bonora and F. Marzatico. Milano: Silvana editore, 2007. 
Mei J. "Qijia and Seima-Turbino: the question of early contacts between Northwest China and the Eurasian steppe." The Bulletin of the Museum of the Far Eastern Antiquities no. 75 (2003): 31-54.

Mei J. Copper and Bronze Age metallurgy in Late Prehistory Xinjiang: its cultural context and relationship with neighbouring regions. Oxford: Archeopress, 2000.

Molodin V.I. and Durakov I.A. "Early and Middle Bronze Age burials at Ordynskoye1, Western Siberia: a new cultural interpretation." Archaeology, Ethnology and Anthropology of Eurasia, no. 41/4 (2013): 84-101.

Museum of Huangyuan. "Preliminary report of the excavation of the Kauyue culture cemetery at the village of Dahuazhong, Huanyuan County, Qinghai." Ziran Kexue shi yanjiu, no. 5 (1985): 11-34.

Qi X., and Wang B. The ancient cultures in Xinjiang along the Silk Road Vol. 2. Urumqi: Xinjiang Renmin chubanshe 2015.

Qi X., Wang B. The ancient cultures in Xinjiang along the Silk Road vol. 1. Urumqi: Xinjiang Renmin chubanshe 2008.

Sarianidi V. I. Necropolis of Gonur. Athens: Kapon Editions, 2007.

Sarianidi V. I. "Le complexe cultuel de Togolok 21 en Margiane" ["Cultural complex of Togolok no. 21 in Margiana"]. Arts Asiatiques, 41, no.1 (1986): 5-21.

Schultz M., Schmidt-Schultz T. H., Wu X. "Results of paleopathological and anthropological examination of human findings from the tomb 26 at Liushui, Xinjiang (China)". Eurasia Antiqua, no.13 (2007): 181-197.

Shao H. "Preliminary discussion on the Zagunluke culture in Xinjiang." Bianjiang kaogu yanjiu, no. 7 (2008): 170-183.

Shelach G. "The Earliest Neolithic Cultures of Northeast China: Recent Discoveries and New Perspectives on the Beginning of Agriculture." Journal of World Prehistory, 14, no. 4 (2000): 363-416.

Song X. "Ancient Chinese mirrors in China and related questions." Kaogu Xuebao no. 2 (1997): 147-169.

Tan J., Li L., Zhang J., Fu W., Guang H., Ao X., Wang L., Wu X., Han K., Jin L. and $\mathrm{Li} \mathrm{H}$. "Craniometrical evidence for population admixture between Eastern and Western Eurasians in Bronze Age southwest Xinjiang." Chinese Science Bulletin, 58, no. 3 (2013): 299-306.

Tang, Z., Mu, G., and Chen, D. "Palaeoenvironment of mid-to late Holocene loess deposit of the southern margin of the Tarim Basin, NW China." Environmental Geology, no. 58, (2009): 1703-1711 :SEEP:

The Sino-French archaeological team. "Outlines of the results from the archaeological excavations in the reaches of the Keriya River." Xinjiang Wenwu, no.4 (1990): 112.

Ts'ui-jung Liu, "A retrospection of climate changes and their impacts in Chinese history." In Nature, Environment and culture in East Asia, edited by C. Meinert, 107-136. Leiden: Brill, 2013.

Vidale M. "Gold and time, searching for new productive relationships in the evolution of the Scythian goldworking." In Gold of the Steppe Riders, Collections from Ukrainian Museums, edited by G. L. Bonora and F. Marzatico. Milano: Silvana editore, 2007.

Vishnevskaya, O. A. "Central Kazakhstan Steppes in the Asian region of the USSR in Scytho-Sarmatian Time." Archaeology of the USSR, 1990.

Wang B., Xiao X., Liu W., Liu W. "Microliths of Aerjin Mountains." Xinjiang Wenwu [Xinjiang Cultural Relics], no.4 (1997): 14-19.

Xinjiang Bowuguang Kaogubu [Department of Archaeology of the Xinjiang Museum]. "Preliminary report of the excavation of the no. 2 cemetery in Zahongluke, Qiemo County." Xinjiang Wenwu, no. 1, 2 (2002): 1-21. 
Xinjiang Shehui Xueyuan Kaogu Yanjiusuo Xinjiangdui [Xinjiang archaeological team, Institute of Archaeology, Chinese Academy of Social Science] "Bronze Age cemetery at Liushui, Yutian County, Xinjiang." Kaogu, no. 7 (2006): 31-40.

Xinjiang weiwu'er zizhi wenhua ting wenwuchu [Xinjiang Uygur Autonomous Region Cultural Department Cultural Relics Office] and Xinjiang daxue lishixi wenbi yu bu zhuanxiuban [Department of History, Xinjiang University]. "The cemetery at Yanbulake in Hami, Xinjiang." Kaogu Xuebao, no. 3 (1989): 329362.

Xinjiang weiwu'erzizhi bowuguan [Regional Museum of Xinjiang] and Bayingeleng menggu zizhizhou wenguansuo [Mongolia Autonomous Prefecture's Bayincolin Office for Cultural Relics Administration] "Report of the excavation of the no. 1 cemetery in Zahongluke village, Qiemo County, Xinjiang." Каogu Хиеbao, no. 1 (2003): 89-136.

Xinjiang Wenwu Kaogu Yanjiu suo [Xinjiang Institute of Archaeology]. "Brief report of the excavation in 1986 of the cemetery IV at Chawuhugou, Hejing County Xinjiang." Xinjiang Wenwu [Xinjinag Cultural Relics], no. 1 (1987): $1-9$.

Xinjiang Wenwu Kaogu Yanjiusuo [Xinjiang Institute of Archaeology] "Summary of excavation at Qiemu'erqieke cemetery." Wenwu, no. 1 (1981): 23-32.

Xinjiang Wenwu Kaogu Yanjiusuo [Xinjiang Institute of Archaeology] "First exploration of the Kezi'ertu'er cemetery in Baicheng County, Xinjiang." Kaogu, no. 6 (2006): 14-29.

Xinjiang Wenwu Kaogu Yanjiusuo [Xinjiang Institute of Archaeology]. The cemetery at Xiabandi. Beijing: Wenwu chubanshe, 2012.

Xinjiang Wenwu Kaogu Yanjiusuo [Xinjiang Institute of Archaeology] "Preliminary report of the 2003 excavation of the Xiaohe cemetery in Lop Nur, Xinjiang." Wenwu, no. 10 (2007): 4-42.

Xinjiang Wenwu Kaogu Yanjiusuo [Xinjiang Institute of Archaeology] "Ancient tombs in Shihezi city." Xinjiang Wenwu, no. 4 (1994): 12-19.

Xinjiang Wenwu Kaogu Yanjiusuo [Xinjiang Institute of Archaeology]. "Brief report of the excavation of the cemetery I at Chawuhugou, Hejing County Xinjiang." Xinjiang Wenwu [Xinjiang Cultural Relics], no. 4 (1992): 11-64;

Xinjiang Wewu'er Zizhiqu Bowuguang Kaogudui [Archaeological team of Museum of Xinjiang Uygur authonomous region], "Investigation in the Neolithic sites at Aketala etc., Shufu County, Xinjiang". Kaogu, no. 2 (1977): 107-110.

Xu X., and Ge S. "On the types and periods of Kayue culture." Qinghai Wenwu, no. 1 (1988): 35-44.

Yablosky, L. T. "The material culture of the Saka and historical reconstruction." In Nomads of the Eurasian Steppe in the Iron Age, edited by J. Davis-Kimball, V. A. Bashilov and L. T. Yablosky, 201-240. Berekly: Zinat Press, 1995.

Yablosky, L. T. "The Saka in Central Asia." In Nomads of the Eurasian Steppe in the Iron Age, edited by J. Davis-Kimball, V. A. Bashilov and L. T. Yablosky. Berekly: Zinat Press, 1995.

Yang X., Liu Z., Zhang F., White P. D., and Wang D. "Hydrological changes and land degradation in the southern and eastern Tarim Basin, Xinjiang, China." Land Degradation and Development, no. 17 (2006): 381-392.

Yue F. and Yu Z. "Investigations conducted on the remains in Niya Beifang district (Xinjiang, Mifeng County) in 1996." Kaogu, no. 4 (1999): 11-17.

Zhang X. and Zhu H. Bioarchaeological "Analysis of Bronze Age Populations of the Liushui Cemetery Using Dental Nonmetric Traits." Acta Anthropologica Sinica, 33, no. 4, (2014): 460-470.

Zhong Riben gongtong Niya yiji xueshu kaochadui [The Sino-Japanese Joint 
Research of the Niya Site]. Report on the investigations at the Niya site by The Sino-Japanese Joint Research team. Urumqi: Buddhist University Niya ruins Academic Research Institution, 1999.

Zhong W., Xiong H., Tashpolat T., Hikori T., and Shu Q. "Historical climate changes in southern Xinjiang." Journal of Geographical Sciences, 11, no. 4 (2001): 449453.

Zhong W., Xiong H., Tashpolat T., Shu Q. "The sequence of paleoenviromental changes since about 4ka BP, recorded by Niya section in Southern margin of Tarim Basin, Chinese." Chinese geographical science, 11, no. 2 (2001): 144149.

Zhongguo kexue yuan kaogu yanjiusuo [Institute of Archaeology, Chinese Academy of Social Science] "Brief report on the excavation of sectors 3 and 8 at Erlitou Yanshi." Kaogu, no.5 (1975): 302-309.

Zhongguo shehui kexueyuan kaogusuo Xinjiangdui [Xinjian team of the Institute of Archaeology, Chinese Academy of Social Science] and Bayingeleng menggu zizhizhou wenguansuo [Mongolia Autonomous Prefecture's Bayincolin Office for Cultural Relics Administration], "Brief report of the excavation of the cemetery I at Chawuhugou, Hejing County Xinjiang". Xinjiang Wenwu, no. 4 (1992): 11-64.

Zu R., Gao Q., Qu J., and Qiang M. "Environmental changes of oases at southern margin of Tarim Basin, China." Environmental Geology, no. 44 (2003): 639-644. 